Check for updates

Cite this: RSC Adv., 2018, 8, 34078

Received 27th July 2018

Accepted 27th September 2018

DOI: $10.1039 / \mathrm{c} 8 \mathrm{ra0} 0335 \mathrm{~d}$

rsc.li/rsc-advances

\title{
Hydrazine-solvothermal methods to synthesize polymeric thioarsenates from one-dimensional chains to a three-dimensional framework $\dagger$
}

\author{
Jingyu Han, ${ }^{a}$ Shufen $\mathrm{Li}^{\mathrm{a}}{ }$ Chunying Tang, ${ }^{\mathrm{b}}$ Wei Zheng, ${ }^{a}$ Wenqing Jiang ${ }^{\mathrm{a}}$ \\ and Dingxian Jia $(\mathbb{D}$ *a
}

A series of polymeric Mn(I)-thioarsenates $\left[\mathrm{Mn}(\mathrm{en})_{3}\right]_{n}\left[\left(\mathrm{~N}_{2} \mathrm{H}_{4}\right)_{2} \mathrm{Mn}_{6}\left(\mu_{6}-\mathrm{S}\right)\left(\mu-\mathrm{N}_{2} \mathrm{H}_{4}\right)_{2}\left(\mu_{3}-\mathrm{AsS}_{3}\right)_{4}\right]_{n}$ $\left[\mathrm{N}_{2} \mathrm{H}_{5}\right]_{n}\left[\left\{\mathrm{Mn}\left(\mu-\mathrm{N}_{2} \mathrm{H}_{4}\right)_{2}\left(\mu-\mathrm{AsS}_{4}\right)\right\} \cdot 0.5 e n\right]_{n} \quad(2), \quad\left[\mathrm{Mn}(\mu-\operatorname{trien})\left\{\mathrm{Mn}\left(\mu-\mathrm{N}_{2} \mathrm{H}_{4}\right)\left(\mu-\mathrm{AsS}_{3}\right)\right\}_{2}\right]_{n} \quad$ (3), $\left[\left\{\mathrm{Mn}_{2}\left(\mathrm{~N}_{2} \mathrm{H}_{4}\right)\right\}_{2}(\mu-\right.$ $\left.\left.\mathrm{N}_{2} \mathrm{H}_{4}\right)_{2}\left\{\mathrm{Mn}\left(\mu-\mathrm{N}_{2} \mathrm{H}_{4}\right)_{2}\left(\mu-\mathrm{AsS}_{3}\right)_{2}\right\}\right]_{n}(4),\left[\mathrm{Mn}_{3}\left(\mu-\mathrm{N}_{2} \mathrm{H}_{4}\right)_{6}\left(\mu_{3}-\mathrm{AsS}_{4}\right)\left(\mu_{2}-\mathrm{AsS}_{4}\right)\right]_{n}(5)$, and $\left[\mathrm{Mn}\left(\mathrm{NH}_{3}\right)_{6}\right]_{n}\left[\mathrm{Mn}_{2}\left(\mathrm{NH}_{3}\right)(\mu-\right.$ $\left.\left.\left.\mathrm{AsS}_{4}\right)\right\}_{2}\right]_{n}$ (6) were synthesized using a hydrazine-solvothermal method. The thioarsenate units $\mathrm{AsS}_{3}$ and $\mathrm{AsS}_{4}$ coordinate to $\mathrm{Mn}(I)$ ions with variable coordination modes, forming a $\mathrm{Mn}-\mathrm{As}-\mathrm{S}$ ternary cluster (1), chains (2, 4-6), and layers (3), respectively. The hydrazine molecules act as inter-cluster, intra-chain and intra-layer bridging ligands to join the $M n(॥)$ ions, resulting in hydrazine hybrid 1-D, 2-D, and 3-D Mn(॥)thioarsenate moieties in 1-5. Compounds 1-6 exhibit tunable semiconducting band gaps varying in the range of $2.19-2.47 \mathrm{eV}$. Compound 1 displays stronger antiferromagnetic coupling interactions than that of compound 2 .

\section{Introduction}

Intense efforts have been continually devoted to the research on organic-inorganic hybrid materials, which not only have fundamental interest in their rich structural diversities but also pose important synthetic challenges and exhibit unique structure-property correlations. ${ }^{1}$ In the wide field of hybrids, chalcogenidometallates of main group metals are attractive for potential applications in a wide field of visible-light photocatalysts, ${ }^{2}$ photoluminescence, ${ }^{3}$ gas separators, ${ }^{4}$ nonlinear optical generators, ${ }^{5}$ photoconductors, ${ }^{6}$ semiconductors, ${ }^{4 a, 7}$ ion exchangers, ${ }^{8}$ and magnetism. ${ }^{9}$ Since Bedard et al. hydrothermally prepared microporous tin and germanium sulfides in aqueous amine solution in the late $1980 \mathrm{~s},{ }^{10}$ the templating synthesis in liquids under mild hydro- or solvo-thermal conditions has been developed to be a versatile approach to the preparation of chalcogenidometallates. A large number of organic-inorganic chalcogenidometallates had been solvothermally prepared in organic solvents (such as organic amine or alkyl alcohol). ${ }^{\mathbf{1 1}}$ In presence of both transition metals

${ }^{a}$ College of Chemistry, Chemical Engineering and Materials Science, Soochow University, No. 199 Renai Road, Suzhou, 215123, P. R. China.E-mail: jiadingxian@ suda.edu.cn

${ }^{b}$ College of Chemistry, Chemical Engineering and Materials Science, Shandong Normal University, No. 88 East Wenhua Road, Jinan, 250014, P. R. China

$\dagger$ Electronic supplementary information (ESI) available: Selected bond lengths and angles, IR spectra, PXRD patterns, structural figures, magnetic measurement, and TG curves. CCDC 1856282-1856287 for 1-6. For ESI and crystallographic data in CIF or other electronic format see DOI: 10.1039/c8ra06335d
(TMs) and coordinative polyamines, the chalcogenidometallates which contain charge compensating cation $\left[\mathrm{TM}(\text { polyamine })_{m}\right]^{n+}$ had been obtained by the solvothermal methods. ${ }^{12}$ Recently, several methodologies have been developed in preparation of the crystalline chalcogenides. Thermal synthesis in ionic liquids (ionothermal method) has been employed in the synthesis of chalcogenidometallates which dominated by the works of Dehnen and Huang. ${ }^{13}$ The work of Zhang has shown that the surfactant-thermal method is a fruitful route to prepare chalcogenidoarsenates and chalcogenidoantimonates. ${ }^{14}$ Apparently, the templating synthesis in liquid make it possible to chose different templates or solvents to affect the thermal reactions, and further to tune the structures and properties of the final products.

Hydrazine $\left(\mathrm{N}_{2} \mathrm{H}_{4}\right)$ is an excellent candidate for the reaction media for the syntheses of chalcogenidometallates because of the unique properties of hydrazine: (1) strong reducing ability (standard reducing potential: $\left.\varphi^{\theta}\left(\mathrm{N}_{2} / \mathrm{N}_{2} \mathrm{H}_{4}\right)=-1.16 \mathrm{~V}\right),(2)$ high polarity (dipole moment $\mu=1.75 \mathrm{D}),{ }^{15,16 a}$ and (3) high coordination aptitude to metal ions with less steric hindrance. As a strong reducing agent, $\mathrm{N}_{2} \mathrm{H}_{4}$ can smoothly reduce elemental chalcogen to form chalcogenide $\mathrm{Q}^{2-}$ anions or polychalcogenide $\mathrm{Q}_{n}{ }^{2-}(\mathrm{Q}=\mathrm{S}, \mathrm{Se}, \mathrm{Te})$ anions. This makes it possible to prepare chalcogenidometallates using elemental chalcogens instead of chalcogenides as starting materials under mild conditions. The high polarity and coordination aptitude of $\mathrm{N}_{2} \mathrm{H}_{4}$ are helpful for dissolving the metal chalcogenide species and prevent them from generating precipitation in the growing crystalline chalcogenides. In fact, hydrazine has been used as a reaction media in preparation of chalcogenides in the last 
decade and several hydrazine-adducts of metal chalcogenides were prepared in hydrazine solution at room temperature. ${ }^{16}$ However, the synthesis in hydrazine solvent under solvothermal conditions (hydrazine-solvothermal) remains less explored. The early works in this area afforded hydrazine-complexes of metal chalcogenides based on 15/16 and 14/16 chalcogenidometallates. ${ }^{17}$ Recently, we successfully prepared the heavier telluromercurates by the hydrazine-solvothermal method using powder Te as the sole tellurium source in the lower temperature range. ${ }^{18}$ In addition, several experiments have demonstrated that the reactive hydrazine molecule is also an important auxiliary reagent in the preparation of crystalline chalcogenidometallates, although it does not appear in the final products. ${ }^{13 b, 13 h, 19}$

Inspired by our previous work on fabrication of TMcontaining chalcogenidoarsenates in different solvents, ${ }^{20}$ we are interested in understanding how the solvent and coordination effects of hydrazine to influence crystal growth of chalcogenidoarsenates under solvothermal conditions. Now, we chose $\mathrm{Mn} / \mathrm{As} / \mathrm{S}$ as a model system to systematically explore the hydrazine-solvothermal syntheses under different conditions. By changing the second solvent, six polymeric Mn(II)-thioarsenates $\left[\mathrm{Mn}(\mathrm{en})_{3}\right]_{n}\left[\left(\mathrm{~N}_{2} \mathrm{H}_{4}\right)_{2} \mathrm{Mn}_{6}\left(\mu_{6}-\mathrm{S}\right)\left(\mu-\mathrm{N}_{2} \mathrm{H}_{4}\right)_{2}\left(\mu_{3}-\mathrm{AsS}_{3}\right)_{4}\right]_{n}$ (1), $\left[\mathrm{N}_{2} \mathrm{H}_{5}\right]_{n}\left[\left\{\mathrm{Mn}\left(\mu-\mathrm{N}_{2} \mathrm{H}_{4}\right)_{2}\left(\mu-\mathrm{AsS}_{4}\right)\right\} \cdot 0.5 \mathrm{en}\right]_{n}(\mathrm{en}=$ ethylenediamine $)$ (2), $\left[\mathrm{Mn}(\mu \text {-trien })\left\{\mathrm{Mn}\left(\mu-\mathrm{N}_{2} \mathrm{H}_{4}\right)\left(\mu-\mathrm{AsS}_{3}\right)\right\}_{2}\right]_{n}$ (trien = triethylenetetramine) (3), $\left[\left\{\mathrm{Mn}\left(\mathrm{N}_{2} \mathrm{H}_{4}\right)\right\}_{2}\left(\mu-\mathrm{N}_{2} \mathrm{H}_{4}\right)_{2}\left\{\mathrm{Mn}\left(\mu-\mathrm{N}_{2} \mathrm{H}_{4}\right)_{2}\left(\mu-\mathrm{AsS}_{3}\right)_{2}\right\}\right]_{n}$ (4), $\left[\mathrm{Mn}_{3}\left(\mu-\mathrm{N}_{2} \mathrm{H}_{4}\right)_{6}\left(\mu_{3}-\mathrm{AsS}_{4}\right)\left(\mu_{2}-\mathrm{AsS}_{4}\right)\right]_{n}$ (5), and $\left[\mathrm{Mn}\left(\mathrm{NH}_{3}\right)_{6}\right]$ ${ }_{n}\left[\left\{\mathrm{Mn}\left(\mathrm{NH}_{3}\right)\left(\mu-\mathrm{AsS}_{4}\right)\right\}_{2}\right]_{n}$ (6) were synthesized in $\mathrm{N}_{2} \mathrm{H}_{4}$ solvent under solvothermal conditions. The 2-D layer of $\mathbf{1}$ featuring a large $\left[\mathrm{Mn}_{6}\left(\mu_{6}-\mathrm{S}\right)\left(\mu_{3}-\mathrm{AsS}_{3}\right)_{4}\right]$ cubic building block and 3-D framework of 3 show the unique synergistic coordination effect of $\mathrm{N}_{2} \mathrm{H}_{4}$ with organic amine. The terminal and bridging coordination modes of $\mathrm{N}_{2} \mathrm{H}_{4}$ ligands lead to various combinations between $\mathrm{Mn}^{2+}$ ion and $\left[\mathrm{AsS}_{3}\right]$ or $\left[\mathrm{AsS}_{4}\right]$ unit in compounds 1-5. This investigation could provide us a better understanding of the different effects of $\mathrm{N}_{2} \mathrm{H}_{4}$ solvent from the traditional organic amine solvent on preparation of $\mathrm{Mn}$-As chalcogenides under solvothermal conditions.

\section{Results and discussion}

\section{Syntheses}

Title compounds were prepared using elements $\mathrm{Mn}$, As, and S as starting materials in $\mathrm{N}_{2} \mathrm{H}_{4}$ solvent under solvothermal conditions in moderate temperature range (Scheme 1).

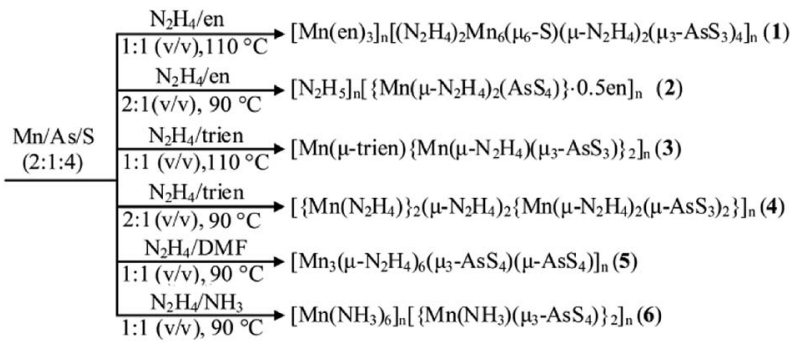

Scheme 1 Solvothermal syntheses of compounds 1-6.
Reaction of $\mathrm{Mn}$, As, and $\mathrm{S}$ in the $1: 1(\mathrm{v} / \mathrm{v}) \mathrm{N}_{2} \mathrm{H}_{4} / \mathrm{en}$ mixed solvent for 6 days produced a thioarsenate(III) $\left[\mathrm{Mn}(\mathrm{en})_{3}\right]_{n}\left[\left(\mathrm{~N}_{2}\right.\right.$ $\left.\left.\mathrm{H}_{4}\right)_{2} \mathrm{Mn}_{6}\left(\mu_{6}-\mathrm{S}\right)\left(\mu-\mathrm{N}_{2} \mathrm{H}_{4}\right)_{2}\left(\mu_{3}-\mathrm{AsS}_{3}\right)_{4}\right]_{n}$ (1). The reaction in the $2: 1$ $(\mathrm{v} / \mathrm{v}) \quad \mathrm{N}_{2} \mathrm{H}_{4} /$ en mixed solvent afforded a thioarsenate(v) $\left[\mathrm{N}_{2} \mathrm{H}_{5}\right]_{n}\left[\left\{\mathrm{Mn}\left(\mu-\mathrm{N}_{2} \mathrm{H}_{4}\right)_{2}\left(\mathrm{AsS}_{4}\right)\right\} \cdot 0.5 \mathrm{en}\right]_{n}$ (2). The same reactions with trien instead of en gave thioarsenates(III) [Mn $(\mu$-trien) $\left.\left\{\mathrm{Mn}\left(\mu-\mathrm{N}_{2} \mathrm{H}_{4}\right)\left(\mu_{3}-\mathrm{AsS}_{3}\right)\right\}_{2}\right]_{n}$ (3) and $\left[\left\{\mathrm{Mn}\left(\mathrm{N}_{2} \mathrm{H}_{4}\right)\right\}_{2}\left(\mu-\mathrm{N}_{2} \mathrm{H}_{4}\right)_{2}\{\mathrm{Mn}(\mu-\right.$ $\left.\left.\left.\mathrm{N}_{2} \mathrm{H}_{4}\right)_{2}\left(\mu-\mathrm{AsS}_{3}\right)_{2}\right\}\right]_{n}(4)$, respectively. $\mathrm{Mn}(\mathrm{II})$ ion does not bind the en or trien molecule in 2 and 4. The reaction in $\mathrm{N}_{2} \mathrm{H}_{4} / \mathrm{DMF}$ and $\mathrm{N}_{2} \mathrm{H}_{4} / \mathrm{NH}_{3}$ (aqueous ammonia, 25\%) mixed solvents produced thioarsenates(v) $\left[\mathrm{Mn}_{3}\left(\mu-\mathrm{N}_{2} \mathrm{H}_{4}\right)_{6}\left(\mu_{3}-\mathrm{AsS}_{4}\right)\left(\mu-\mathrm{AsS}_{4}\right)\right]_{n} \quad$ (5) and $\left[\mathrm{Mn}\left(\mathrm{NH}_{3}\right)_{6}\right]_{n}\left[\left\{\mathrm{Mn}\left(\mathrm{NH}_{3}\right)\left(\mu_{3}-\mathrm{AsS}_{4}\right)\right\}_{2}\right]_{n}(6)$, respectively. It is noteworthy that $\mathrm{N}_{2} \mathrm{H}_{4}$ molecule does not appear in compound 6 . However, the attempt to synthesize $\mathbf{6}$ in ammonia solution without $\mathrm{N}_{2} \mathrm{H}_{4}$ had failed. The reactions without $\mathrm{N}_{2} \mathrm{H}_{4}$ in the temperature range $100-160{ }^{\circ} \mathrm{C}$ produced yellow solutions and small amount of grey precipitates. In compounds 1-5, $\mathrm{N}_{2} \mathrm{H}_{4}$ molecule acts as a ligand to the $\mathrm{Mn}^{2+}$ ion, and as a counterion in protonated form in compound 2 . In the FT-IR spectra of compounds 1-5, the bands located between 986 and $996 \mathrm{~cm}^{-1}$ are attributed to the $\mathrm{N}-\mathrm{N}$ vibrations of $\mathrm{N}_{2} \mathrm{H}_{4}$ molecules (Fig. S1$\mathrm{S} 5 \dagger) .{ }^{17 a, 17 c}$ The purity of bulk phases of title compounds were investigated using powder X-ray diffraction (PXRD). The PXRD patterns of title compounds are consistent with the simulated PXRD patterns based on single-crystal XRD data (Fig. S7†), respectively.

\section{Crystal structures}

Compound 1 crystallizes in the monoclinic space group $P 2_{1} / c$ with four formulae in the unit cell (Table S1 $\dagger$ ). It consists of a $\left[\mathrm{Mn}(\mathrm{en})_{3}\right]^{2+}$ complex cation, a 2-D $\left[\left(\mathrm{N}_{2} \mathrm{H}_{4}\right)_{2} \mathrm{Mn}_{6}\left(\mu_{6}-\mathrm{S}\right)(\mu-\right.$ $\left.\left.\mathrm{N}_{2} \mathrm{H}_{4}\right)_{2}\left(\mu_{3}-\mathrm{AsS}_{3}\right)_{4}{ }^{2-}\right]_{n}$ polymeric anion. The 2 -D polymeric anion is constructed from a $\left[\mathrm{Mn}_{6}\left(\mu_{6}-\mathrm{S}\right)\left(\mu_{3}-\mathrm{AsS}_{3}\right)_{4}\right]$ cluster and hydrazine molecules. There are four crystallographically independent As, seven $\mathrm{Mn}$, and thirteen $\mathrm{S}$ atoms in 1. Each $\mathrm{As}^{3+}$ ion is coordinated by three $\mathrm{S}^{2-}$ anions, forming a typical trigonal pyramid $\mathrm{AsS}_{3}$, which acts as the primary building unit (PBU). One $\mathrm{AsS}_{3}$ PBU chelates three $\mathrm{Mn}^{2+}$ ions as a $\mu_{3}-\mathrm{AsS}_{3}$ ligand, forming a $\mathrm{Mn}_{3} \mathrm{AsS}_{3}$ semi-cube (Fig. 1a). The three $\mathrm{Mn}^{2+}$ ions of $\mathrm{Mn}_{3} \mathrm{AsS}_{3}$ are capped by a $\mathrm{S}^{2-}(\mathrm{S} 1)$ anion to form a $\left[\mathrm{Mn}_{3}\left(\mu_{3}-\mathrm{S}\right)\left(\mu_{3^{-}}\right.\right.$ $\left.\mathrm{AsS}_{3}\right)$ ] cube (highlighted by purple bonds in Fig. 1a), which can be regarded as the secondary building unit (SBU). Four $\left[\mathrm{Mn}_{3}\left(\mu_{3}-\right.\right.$ $\left.\mathrm{S})\left(\mu_{3}-\mathrm{AsS}_{3}\right)\right]$ cubic SBUs are joined via edge-sharing forming a cube-like heterometallic cluster $\left[\mathrm{Mn}_{6}\left(\mu_{6}-\mathrm{S}\right)\left(\mu_{3}-\mathrm{AsS}_{3}\right)_{4}\right]$ (Fig. 1a). As a result, the $\mathrm{S} 1$ atom occupies the heart of the cubic cluster, and binds six Mn atoms as a $\mu_{6}$-S bridging ligand (Fig. 1b), whilst four $\mathrm{As}^{3+}$ cations occupy four vertexes and six $\mathrm{Mn}^{2+}$ cations are located at the face-centers of the cubic cluster. Each $\mathrm{Mn}^{2+}$ cation is further coordinated by a $\mathrm{N}$ atom from $\mathrm{N}_{2} \mathrm{H}_{4}$ molecule forming an octahedral coordination environment of $\mathrm{MnS}_{5} \mathrm{~N}$ (Fig. 1a). The $\mathrm{S}^{2-}$ anions have two different coordination modes in the $\left[\mathrm{Mn}_{6}\left(\mu_{6}-\mathrm{S}\right)\left(\mu_{3}-\mathrm{AsS}_{3}\right)_{4}\right]^{2-}$ cube. Except for the central $S(1)^{2-}$ ion with a $\mu_{6}$-S bridging mode (Fig. 1b), the remaining 12 sulfide anions (S2-S13) have the same $\mu_{3}-\mathrm{S}$ bridging modes binding two $\mathrm{Mn}^{2+}$ and one $\mathrm{As}^{3+}$ cations. The structure of the $\left[\mathrm{Mn}_{6}\left(\mu_{6}-\mathrm{S}\right)\left(\mu_{3}-\mathrm{AsS}_{3}\right)_{4}\right]^{2-}$ cubic cluster is 


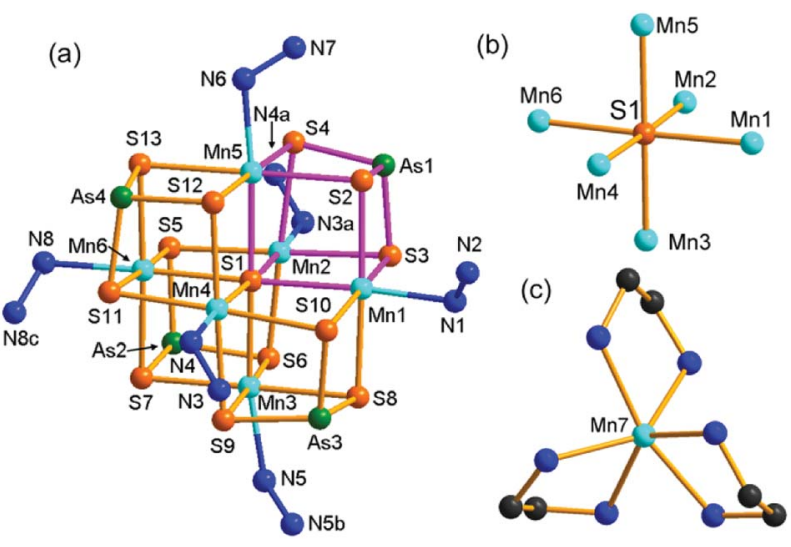

Fig. 1 Structures for compound 1: $\left[\left(\mathrm{N}_{2} \mathrm{H}_{4}\right)_{2} \mathrm{Mn}_{6}\left(\mu_{6}-\mathrm{S}\right)\left(\mu-\mathrm{N}_{2} \mathrm{H}_{4}\right)_{2}\left(\mu_{3}-\right.\right.$ $\left.\left.\mathrm{AsS}_{3}\right)_{4}\right]^{2-}$ cluster showing the $\left[\mathrm{Mn}_{3}\left(\mu_{3}-\mathrm{S}\right)\left(\mu_{3}-\mathrm{AsS}_{3}\right)_{4}\right]$ cube highlighted in purple bonds (a), $\mathrm{Mn}_{6}\left(\mu_{6}-\mathrm{S}\right)$ octahedron (b), and $\left[\mathrm{Mn}(\mathrm{en})_{3}\right]^{2+}$ complex cation (c). Hydrogen atoms are omitted for clarity. Symmetry codes: (a) $x-1, y, z$; (b) $-x,-y+1,-z$; (c) $-x+1,-y+1,-z+1$.

characterized by an octahedral core $\mathrm{Mn}_{6}\left(\mu_{6}-\mathrm{S}\right)$ (Fig. $\left.1 \mathrm{~b}\right)$ which is constructed from the heart $\mathrm{S}^{2-}$ anion and the six $\mathrm{Mn}^{2+}$ cations at the face-centers of the $\left[\mathrm{Mn}_{6}\left(\mu_{6}-\mathrm{S}\right)\left(\mu_{3}-\mathrm{AsS}_{3}\right)_{4}\right]^{2-}$ cube. The connectivity within the $\left[\mathrm{Mn}_{6}\left(\mu_{6}-\mathrm{S}\right)\left(\mu_{3}-\mathrm{AsS}_{3}\right)_{4}\right]^{2-}$ cluster is more easily understood when the $\mathrm{Mn}_{6}\left(\mu_{6}-\mathrm{S}\right)$ octahedron is capped by four $\mu_{3}-\mathrm{AsS}_{3}$ ligands at four opposite faces (Fig. S8 $\dagger$ ). The As-S, and $\mathrm{Mn}-\mathrm{S}$ bond lengths (Table S2 $\dagger$ ) are in agreement with those observed in Mn-thioarsenates(III)..$^{9 b, 9 c, 20 d}$ The $\mathrm{Mn}(7)^{2+}$ ion is coordinated to six $\mathrm{N}$ atoms from three en ligands, forming a distorted octahedral $\left[\mathrm{Mn}(\mathrm{en})_{3}\right]^{2+}$ complex cation (Fig. 1c).

In compound 1 , the $\left[\mathrm{Mn}_{6}\left(\mu_{6}-\mathrm{S}\right)\left(\mu_{3}-\mathrm{AsS}_{3}\right)_{4}\right]^{2-}$ clusters are connected via hydrazine molecules into a layered structure. There are two coordination types for the $\mathrm{N}_{2} \mathrm{H}_{4}$ molecule binding the Mn(II) centers. Four Mn(II) ions (Mn2, Mn3, Mn4, Mn6) of the $\left[\mathrm{Mn}_{6}\left(\mu_{6}-\mathrm{S}\right)\left(\mu_{3}-\mathrm{AsS}_{3}\right)_{4}\right]^{2-}$ cluster are respectively linked to four neighbor $\left[\mathrm{Mn}_{6}\left(\mu_{6}-\mathrm{S}\right)\left(\mu_{3}-\mathrm{AsS}_{3}\right)_{4}\right]^{2-}$ clusters via four bidentate $\mu-$ $\mathrm{N}_{2} \mathrm{H}_{4}$ ligands, while the two remaining $\mathrm{Mn}$ (II) ions (Mn1, Mn5) at the neighbor face are terminated by a monodentate $\mathrm{N}_{2} \mathrm{H}_{4}$ ligand (Fig. 2a). As a result, the $\left[\mathrm{Mn}_{6}\left(\mu_{6}-\mathrm{S}\right)\left(\mu_{3}-\mathrm{AsS}_{3}\right)_{4}\right]^{2-}$ clusters are connected into a 2-D $\left[\left(\mathrm{N}_{2} \mathrm{H}_{4}\right)_{2} \mathrm{Mn}_{6}\left(\mu_{6}-\mathrm{S}\right)\left(\mu-\mathrm{N}_{2} \mathrm{H}_{4}\right)_{2}\left(\mu_{3}-\right.\right.$
$\left.\left.\mathrm{AsS}_{3}\right)_{4}{ }^{2-}\right]_{n}$ waved layer perpendicular to the $b$ axis (Fig. 2b and S9a†). Parallel stacking of the waved layers generates squareshaped channels running along the $a$ axis of the unit cell, and the $\left[\mathrm{Mn}(\mathrm{en})_{3}\right]^{2+}$ counter cations are wrapped in the channels between the layers (Fig. S9b†). Weak $\mathrm{N}-\mathrm{H} \cdots \mathrm{S}$ hydrogen bonds are observed between the layers with the donor of $\mathrm{NH}_{2}$ groups from $\mathrm{N}_{2} \mathrm{H}_{4}$ molecules, and acceptor of $\mathrm{S}$ atom from the $\left[\mathrm{Mn}_{6}\left(\mu_{6}-\right.\right.$ S) $\left.\left(\mu_{3}-\mathrm{AsS}_{3}\right)_{4}\right]^{2-}$ cluster (Table S8 $\dagger$ ). The inter-layer hydrogen bonds connected $\left[\left(\mathrm{N}_{2} \mathrm{H}_{4}\right)_{2} \mathrm{Mn}_{6}\left(\mu_{6}-\mathrm{S}\right)\left(\mu-\mathrm{N}_{2} \mathrm{H}_{4}\right)_{2}\left(\mu_{3}-\mathrm{AsS}_{3}\right)_{4}{ }^{2-}\right]_{n}$ layers into a 3D network.

In our previous work, we prepared $\mathrm{Mn}$ (II)-thioarsenates $\left[\mathrm{Mn}(\text { dien })_{2}\right]\left[\mathrm{Mn}_{6}\left(\mu_{6}-\mathrm{S}\right)\left(\mu-\mathrm{N}_{2} \mathrm{H}_{4}\right)_{3}\left(\mu_{3}-\mathrm{AsS}_{3}\right)_{4}\right] \cdot \mathrm{H}_{2} \mathrm{O}$ (dien = diethylenetriamine) [7, monoclinic, $C c$ (no. 9)] and $\left[\mathrm{Mn}(1,2-\mathrm{dap})_{3}\right]$ $\left[\left(\mathrm{N}_{2} \mathrm{H}_{4}\right)_{2} \mathrm{Mn}_{6}\left(\mu_{6}-\mathrm{S}\right)\left(\mu-\mathrm{N}_{2} \mathrm{H}_{4}\right)_{2}\left(\mu_{3}-\mathrm{AsS}_{3}\right)_{4}\right]$ (1,2-dap = 1,2-diaminopropane) $\left[8\right.$, monoclinic, $P 2_{1}$ (no. 4$\left.)\right]$ in the dien $/ \mathrm{N}_{2} \mathrm{H}_{4}$ or 1,2-dap $/ \mathrm{N}_{2} \mathrm{H}_{4}$ mixed solvents, respectively. ${ }^{20 d}$ The $\left[\mathrm{Mn}_{6}\left(\mu_{6}-\mathrm{S}\right)\left(\mu_{3}\right.\right.$ $\left.\left.\mathrm{AsS}_{3}\right)_{4}\right]^{2-}$ cluster is connected into a 3-D $\left\{\mathrm{Mn}_{6}\left(\mu_{6}-\mathrm{S}\right)(\mu-\right.$ $\left.\left.\left.\mathrm{N}_{2} \mathrm{H}_{4}\right)_{3}\left(\mu_{3}-\mathrm{AsS}_{3}\right)_{4}\right]^{2-}\right\}_{n}$ anionic framework via three $\mu-\mathrm{N}_{2} \mathrm{H}_{4}$ bridging ligands in 7, while it is connected into a 2-D $\left\{\left[\left(\mathrm{N}_{2} \mathrm{H}_{4}\right)_{2} \mathrm{Mn}_{6}\left(\mu_{6}-\mathrm{S}\right)\left(\mu-\mathrm{N}_{2} \mathrm{H}_{4}\right)_{2}\left(\mu_{3}-\mathrm{AsS}_{3}\right)_{4}\right]^{2-}\right\}_{n}$ anionic layer via two $\mu-\mathrm{N}_{2} \mathrm{H}_{4}$ bridging ligands in 8 . Compound 1 contains the same 2D $\left\{\left[\left(\mathrm{N}_{2} \mathrm{H}_{4}\right)_{2} \mathrm{Mn}_{6}\left(\mu_{6}-\mathrm{S}\right)\left(\mu-\mathrm{N}_{2} \mathrm{H}_{4}\right)_{2}\left(\mu_{3}-\mathrm{AsS}_{3}\right)_{4}\right]^{2-}\right\}_{n}$ anionic layer as the anionic layer of compound 8. But it crystallizes in a different space group of $P 2_{1} / c$ (no. 14). Contrarily, the $\left[\mathrm{Mn}_{6}\left(\mu_{6}-\mathrm{S}\right)\left(\mu_{3}-\right.\right.$ $\left.\mathrm{AsS}_{3}\right)_{4}$ ] clusters observed in 1, 7, and $\mathbf{8}$ had been never obtained for the syntheses of $\mathrm{Mn} / \mathrm{As} / \mathrm{S}$ in en, dien or 1,2-dap without addition of $\mathrm{N}_{2} \mathrm{H}_{4},{ }^{21}$ indicating the unique templating effect of $\mathrm{N}_{2} \mathrm{H}_{4}$ in the crystal growth of thioarsenates.

Compound 2 crystallizes in the orthorhombic space group $\mathrm{Pbca}$ with eight formulae in the unit cell. It consists of a protonated hydrazine $\left[\mathrm{N}_{2} \mathrm{H}_{5}\right]^{+}$cation, a 1-D polymeric $[\{\mathrm{Mn}(\mu-$ $\left.\left.\left.\mathrm{N}_{2} \mathrm{H}_{4}\right)_{2}\left(\mu-\mathrm{AsS}_{4}\right)\right\}^{-}\right]_{n}$ anion, and half an en molecule. There are one crystallographically independent $\mathrm{Mn}$, one As, and four $\mathrm{S}$ atoms in 2. The $\mathrm{As}^{5+}$ ion is coordinated with four $\mathrm{S}^{2-}$ ions to form an $\left[\mathrm{AsS}_{4}\right]^{3-}$ unit. As shown in Fig. 3, the $\mathrm{Mn}^{2+}$ ion is repeatedly linked by two $\mu-\mathrm{N}_{2} \mathrm{H}_{4}$ bridging ligands, forming an infinite $\left[\mathrm{Mn}\left(\mu-\mathrm{N}_{2} \mathrm{H}_{4}\right)_{2}{ }^{2+}\right]_{n}$ chain. The $\mathrm{Mn}$ (II) centers of the $[\mathrm{Mn}(\mu-$ $\left.\left.\mathrm{N}_{2} \mathrm{H}_{4}\right)_{2}{ }^{2+}\right]_{n}$ are further joined by $\mathrm{S} 1$ of the $\left[\mathrm{AsS}_{4}\right]^{3-}$ unit, giving the chain-like $\left[\left\{\mathrm{Mn}\left(\mu-\mathrm{N}_{2} \mathrm{H}_{4}\right)_{2}\left(\mu-\mathrm{AsS}_{4}\right)\right\}^{-}\right]_{n}$ polymeric anion
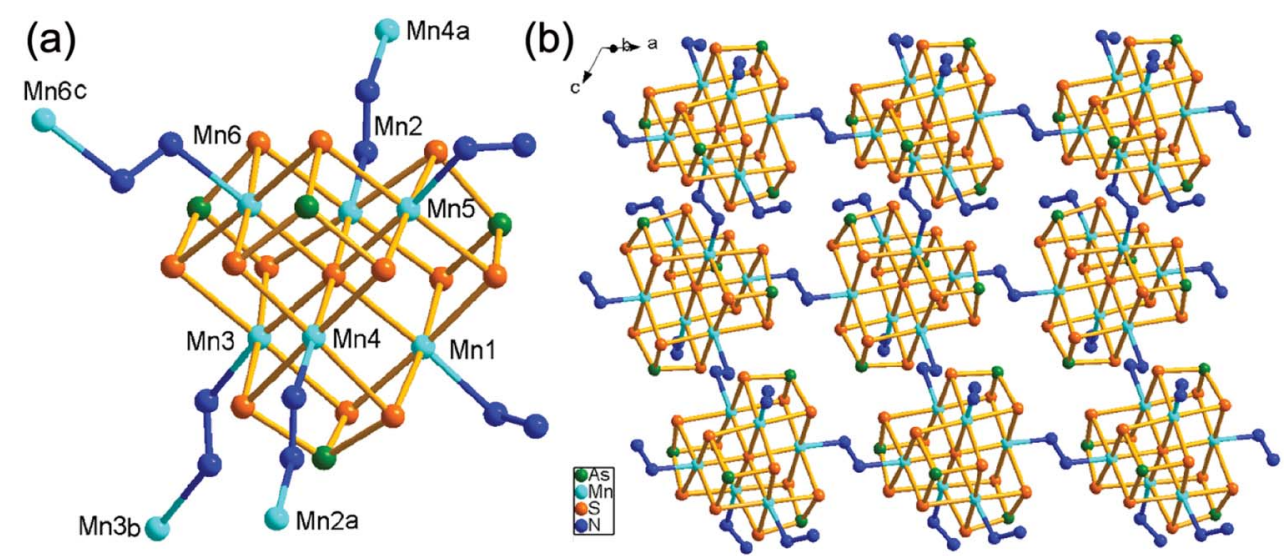

Fig. 2 Structures of the $\left[\mathrm{Mn}_{6}\left(\mu_{6}-\mathrm{S}\right)\left(\mu_{3}-\mathrm{AsS}_{3}\right)_{4}\right]$ cluster showing the $\mathrm{N}_{2} \mathrm{H}_{4}$ linkers between the $\mathrm{Mn}(I)$ ions $(a)$, and the $2 \mathrm{D}\left[\left(\mathrm{N}_{2} \mathrm{H}_{4}\right)_{2} \mathrm{Mn}_{6}\left(\mu_{6}-\mathrm{S}\right)(\mu-\right.$ $\left.\left.\mathrm{N}_{2} \mathrm{H}_{4}\right)_{2}\left(\mu_{3}-\mathrm{AsS}_{3}\right)_{4}{ }^{2-}\right]_{n}$ network (b) in 1 . Symmetry codes: (a) $x-1, y, z$; (b) $-x,-y+1,-z$; (c) $-x+1,-y+1,-z+1$. 


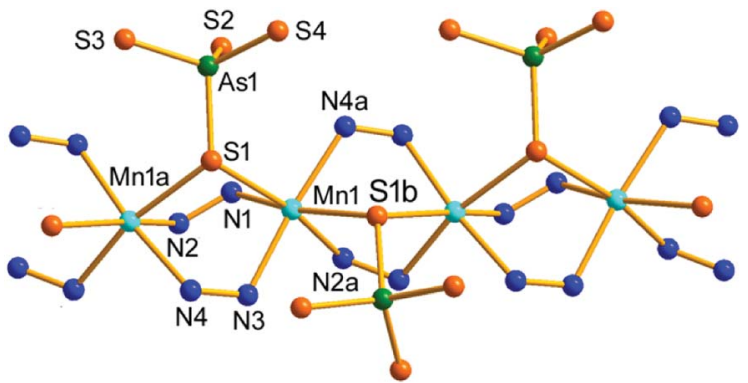

Fig. 3 Structure of the $\left[\left\{\mathrm{Mn}\left(\mu-\mathrm{N}_{2} \mathrm{H}_{4}\right)_{2}\left(\mu-\mathrm{AsS}_{4}\right)\right\}^{-}\right]_{n}$ anionic chain in 2 with the labeling scheme. Symmetry codes: (a) $x-1 / 2, y,-z+1 / 2$; (b) $x$ $+1 / 2, y,-z+1 / 2$.

(Fig. 3). The third hydrazine molecule exists as monoprotonated $\left[\mathrm{N}_{2} \mathrm{H}_{5}\right]^{+}$cation to act as the counter ion of the polymeric anion. The $\left[\mathrm{AsS}_{4}\right]^{3-}$ unit exhibits tetrahedral geometry with S-As-S bond angles in the range of 104.24(15)-112.67(18) ${ }^{\circ}$ (Table S3 $\dagger$ ). The As-S bond lengths are shorter than those of $\left[\mathrm{AsS}_{3}\right]^{3-}$ observed in compound 1 (Tables S2 and S3†). The $\mathrm{Mn}^{2+}$ ion is coordinated by four $\mathrm{N}$ and two $\mathrm{S}$ atoms, forming a distorted octahedron $\mathrm{MnN}_{4} \mathrm{~S}_{2}$ with axial angles varying in the range of 165.8(4)-173.0(4) ${ }^{\circ}$. The $\mathrm{Mn}-\mathrm{S}$ and $\mathrm{Mn}-\mathrm{N}$ bond lengths are consistent with the corresponding bond lengths found in compound 1 (Tables S2 and S3 $\dagger$ ). The $\left[\left\{\mathrm{Mn}\left(\mu-\mathrm{N}_{2} \mathrm{H}_{4}\right)_{2}\left(\mu-\mathrm{AsS}_{4}\right)\right\}^{-}\right]_{n}$ anionic chains run parallel along the $a$ axis and stack a layer via $\mathrm{N}-\mathrm{H} \cdots \mathrm{S}$ hydrogen bonds (Fig. 3). $\left[\mathrm{N}_{2} \mathrm{H}_{5}\right]^{+}$cation and en molecules are located between the anionic layers (Fig. S10 $\dagger$ ).

Compound 3 crystallizes in the triclinic space group $P \overline{1}$ with one formula in the unit cell. It contains one crystallographically independent As, three half $\mathrm{Mn}$, and four S atoms. As shown in Fig. 4, the $\mathrm{As}^{3+}$ ion is coordinated with three $\mathrm{S}^{2-}$ anions to form a typical trigonal pyramid $\mathrm{AsS}_{3}$ with $\mathrm{As}-\mathrm{S}$ bond lengths ranging $2.337(5)-2.350(4) \AA$ (Table $\mathrm{S} 4 \dagger)$. $\mathrm{Mn}(1)^{2+}$ is coordinated by two $\mathrm{S}$ atoms from two $\mathrm{AsS}_{3}$ trigonal pyramids, and four $\mathrm{N}$ atoms from two trien molecules, forming a distorted octahedron $\mathrm{MnS}_{2} \mathrm{~N}_{4}$ with axial angles in the range of 79.4(5)-100.6(5) ${ }^{\circ} \cdot \mathrm{Mn}(2)^{2+}$ and $\mathrm{Mn}(3)^{2+}$ ions are joined by a $\mu-\mathrm{N}_{2} \mathrm{H}_{4}$ bridging ligand, and are capped by the $\mathrm{AsS}_{3}$ unit with S1 binding Mn2, S3 binding Mn3, and S2 binding both Mn2 and Mn3. Meanwhile, the S1 atom

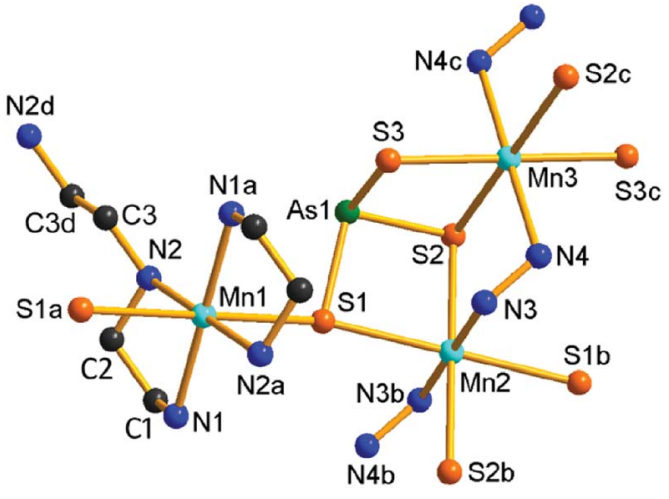

Fig. 4 The asymmetric structural unit of 3 with the labeling scheme, showing coordination environments of each $\mathrm{Mn}^{2+}$ ion. Hydrogen atoms are omitted for clarity. Symmetry codes: (a) $-x+1,-y+1,-z+$ 1; (b) $-x,-y+1,-z+2$; (c) $-x,-y+2,-z+2$; (d) $x, y-1, z$. coordinates to $\mathrm{Mn} 1$, and the asymmetric structural unit $[\mathrm{Mn}(\mu-$ trien) $\left.\left\{\mathrm{Mn}\left(\mu-\mathrm{N}_{2} \mathrm{H}_{4}\right)\left(\mu_{3}-\mathrm{AsS}_{3}\right)\right\}_{2}\right]$ of 3 is formed (Fig. 4). Both $\mathrm{Mn}(2)^{2+}$ and $\mathrm{Mn}(3)^{2+}$ ions are octahedrally coordinated by four $\mathrm{S}$ atoms from two $\mathrm{AsS}_{3}$ units, and two $\mathrm{N}$ atoms from two $\mu-\mathrm{N}_{2} \mathrm{H}_{4}$ ligands, forming $\mathrm{MnS}_{4} \mathrm{~N}_{2}$ octahedra. The $\mathrm{Mn}-\mathrm{S}$ and $\mathrm{Mn}-\mathrm{N}$ bond lengths are comparable to the corresponding bond lengths found in compound $\mathbf{1}$ and $\mathbf{2}$ (Tables S2-S4†).

In 3 , the trien molecule acts as a tetradentate $\mu$-trien bridging ligand. It chelates a $\mathrm{Mn}(1)^{2+}$ ion with two $\mathrm{N}$ atoms, and chelates another $\mathrm{Mn}(1)^{2+}$ ion with the remaining two $\mathrm{N}$ atoms. As a result, the $\operatorname{Mn}(1)^{2+}$ ions are repeatedly joined by the $\mu$-trien bridging ligands, forming an infinite planar $[\{\operatorname{Mn}(1)(\mu-$ trien) $\left.\}^{2+}\right]_{n}$ chain (Fig. 5a). It is notable that the tetradentate amine trien usually chelates the same $\mathrm{TM}^{2+}$ ion with four $\mathrm{N}$ atoms in the syntheses of TM-containing chalcogenidometallates. ${ }^{22}$ The $\mu$-trien bridging ligand in 3 is seldom observed, and only few examples were reported. ${ }^{23}$ The $\operatorname{Mn}(2)^{2+}$ and $\mathrm{Mn}(3)^{2+}$ ions are interconnected by a $\mu_{3}-\mathrm{AsS}_{3}$ and a $\mu-\mathrm{N}_{2} \mathrm{H}_{4}$ bridging ligands, generating an infinite $\left[\mathrm{Mn}_{2}\left\{\left(\mu-\mathrm{N}_{2} \mathrm{H}_{4}\right)\left(\mu_{3}-\right.\right.\right.$ $\left.\left.\left.\mathrm{AsS}_{3}\right)\right\}_{2}{ }^{2-}\right]_{n}$ chain (Fig. 5b). The S1 atoms of the $\left[\mathrm{Mn}_{2}\{(\mu-\right.$ $\left.\left.\left.\mathrm{N}_{2} \mathrm{H}_{4}\right)\left(\mu_{3}-\mathrm{AsS}_{3}\right)\right\}_{2}{ }^{2-}\right]_{n}$ chain coordinate to the $\mathrm{Mn}(1)^{2+}$ ions on both sides of the planar $\left[\{\mathrm{Mn}(1)(\mu \text {-trien })\}^{2+}\right]_{n}$ chain (Fig. 5 a and b), to complete coordination number of six for the $\operatorname{Mn}(1)^{2+}$ ion. As a result, a neutral 3-D framework of $\left[\mathrm{Mn}(\mu\right.$-trien $)\left(\mathrm{Mn}_{2}\{(\mu-\right.$ $\left.\left.\left.\left.\mathrm{N}_{2} \mathrm{H}_{4}\right)\left(\mu-\mathrm{AsS}_{3}\right)\right\}_{2}\right)\right]_{n}$ is obtained (Fig. 5c). In the framework, the $\left[\{\mathrm{Mn}(\mu \text {-trien })\}^{2+}\right]_{n}$ cationic chains run along the $a$ axis, while the $\left[\mathrm{Mn}_{2}\left\{\left(\mu-\mathrm{N}_{2} \mathrm{H}_{4}\right)\left(\mu_{3}-\mathrm{AsS}_{3}\right)\right\}_{2}{ }^{2-}\right]_{n}$ anionic chains run along the $b$ axis of the unit cell (Fig. $5 \mathrm{c}$ and $\mathrm{d}$ ). Intermolecular $\mathrm{N}-\mathrm{H} \cdots \mathrm{S}$ hydrogen bonds are observed between the cationic and anionic chains (Fig. S11, Table S8†).

Compound 4 crystallizes in the triclinic space group $P \overline{1}$. It consists of a neutral $\left[\left\{\mathrm{Mn}\left(\mathrm{N}_{2} \mathrm{H}_{4}\right)\right\}_{2}\left\{\mathrm{Mn}\left(\mu-\mathrm{N}_{2} \mathrm{H}_{4}\right)_{2}\left(\mu-\mathrm{AsS}_{3}\right)_{2}\right\}(\mu-\right.$ $\left.\left.\mathrm{N}_{2} \mathrm{H}_{4}\right)_{2}\right]_{n}$ chain. The chain is composed of two and two halves crystallographically independent $\mathrm{Mn}$, two As, and six S atoms. As shown in Fig. 6, $\mathrm{As}(1)^{3+}$ and $\mathrm{As}(2)^{3+}$ ions are both coordinated with three $\mathrm{S}^{2-}$ anions to form trigonal pyramids $\operatorname{As}(1) \mathrm{S}_{3}$ and $\operatorname{As}(2) \mathrm{S}_{3}$, respectively. $\mathrm{Mn}(1)^{2+}$ and $\mathrm{Mn}(2)^{2+}$ ions are joined by a $\mu-$ $\mathrm{N}_{2} \mathrm{H}_{4}$ bridging ligand and by the $\mathrm{As}(1) \mathrm{S}_{3}$ trigonal pyramid in $\mu$ $\mathrm{AsS}_{3}$ coordination mode, meanwhile the $\mathrm{Mn}(2)^{2+}$ ion binds a terminal $\mathrm{N}_{2} \mathrm{H}_{4}$ molecule. As a result, a binuclear $\left[\mathrm{Mn}_{2}\left(\mathrm{~N}_{2} \mathrm{H}_{4}\right)\left(\mu-\mathrm{N}_{2} \mathrm{H}_{4}\right)\left(\mu-\mathrm{AsS}_{3}\right)\right]$ subunit is formed. The subunit propagates via centrosymmetric operation at $\mathrm{Mn} 1$, forming a trinuclear $\left[\left\{\mathrm{Mn}\left(\mathrm{N}_{2} \mathrm{H}_{4}\right)\right\}_{2}\left\{\mathrm{Mn}\left(\mu-\mathrm{N}_{2} \mathrm{H}_{4}\right)_{2}\left(\mu-\mathrm{AsS}_{3}\right)_{2}\right\}\right] \mathrm{SBU}$ (Fig. 6). By the same connectivities with four $\mathrm{N}_{2} \mathrm{H}_{4}$ (containing N9-N12) molecules, $\operatorname{As}(2) \mathrm{S}_{3}, \mathrm{Mn}(3)^{2+}$ and $\mathrm{Mn}(4)^{2+}$ form another trinuclear $\left[\left\{\mathrm{Mn}\left(\mathrm{N}_{2} \mathrm{H}_{4}\right)\right\}_{2}\left\{\mathrm{Mn}\left(\mu-\mathrm{N}_{2} \mathrm{H}_{4}\right)_{2}\left(\mu-\mathrm{AsS}_{3}\right)_{2}\right\}\right]$ SBU. The two SBUs are alternately connected by two $\mu-\mathrm{N}_{2} \mathrm{H}_{4}$ (containing N3-N6) bridges into a neutral infinite $\left[\left\{\mathrm{Mn}\left(\mathrm{N}_{2} \mathrm{H}_{4}\right)\right\}_{2}\left\{\mathrm{Mn}\left(\mu-\mathrm{N}_{2} \mathrm{H}_{4}\right)_{2}(\mu-\right.\right.$ $\left.\left.\left.\mathrm{AsS}_{3}\right)_{2}\right\}\left(\mu-\mathrm{N}_{2} \mathrm{H}_{4}\right)_{2}\right]_{n}$ chain (Fig. 6). In the neutral chain, hydrazine molecules adopt two types of coordination modes of monodentate terminal mono- $\mathrm{N}_{2} \mathrm{H}_{4}$ and bidentate bridging $\mu-\mathrm{N}_{2} \mathrm{H}_{4}$ to $\mathrm{Mn}$ (II) centers. All $\mathrm{Mn}^{2+}$ ions are in octahedral geometries with $\mathrm{MnS}_{4} \mathrm{~N}_{2}\left(\mathrm{Mn}(1)^{2+}, \mathrm{Mn}(4)^{2+}\right)$ and $\mathrm{MnS}_{2} \mathrm{~N}_{4}\left(\mathrm{Mn}(2)^{2+}, \mathrm{Mn}(3)^{2+}\right)$ donor sets. In 4 , the $\left[\left\{\mathrm{Mn}\left(\mathrm{N}_{2} \mathrm{H}_{4}\right)\right\}_{2}\left\{\mathrm{Mn}\left(\mu-\mathrm{N}_{2} \mathrm{H}_{4}\right)_{2}\left(\mu-\mathrm{AsS}_{3}\right)_{2}\right\}(\mu-\right.$ $\left.\left.\mathrm{N}_{2} \mathrm{H}_{4}\right)_{2}\right]_{n}$ chains run parallel, and interact with each other via intermolecular $\mathrm{N}-\mathrm{H} \cdots \mathrm{N}$ and $\mathrm{N}-\mathrm{H} \cdots \mathrm{S}$ hydrogen bonds (Table $\mathrm{S} 8 \dagger$ ), forming layers parallelling with the (111) plane (Fig. S12 $\dagger$ ). 

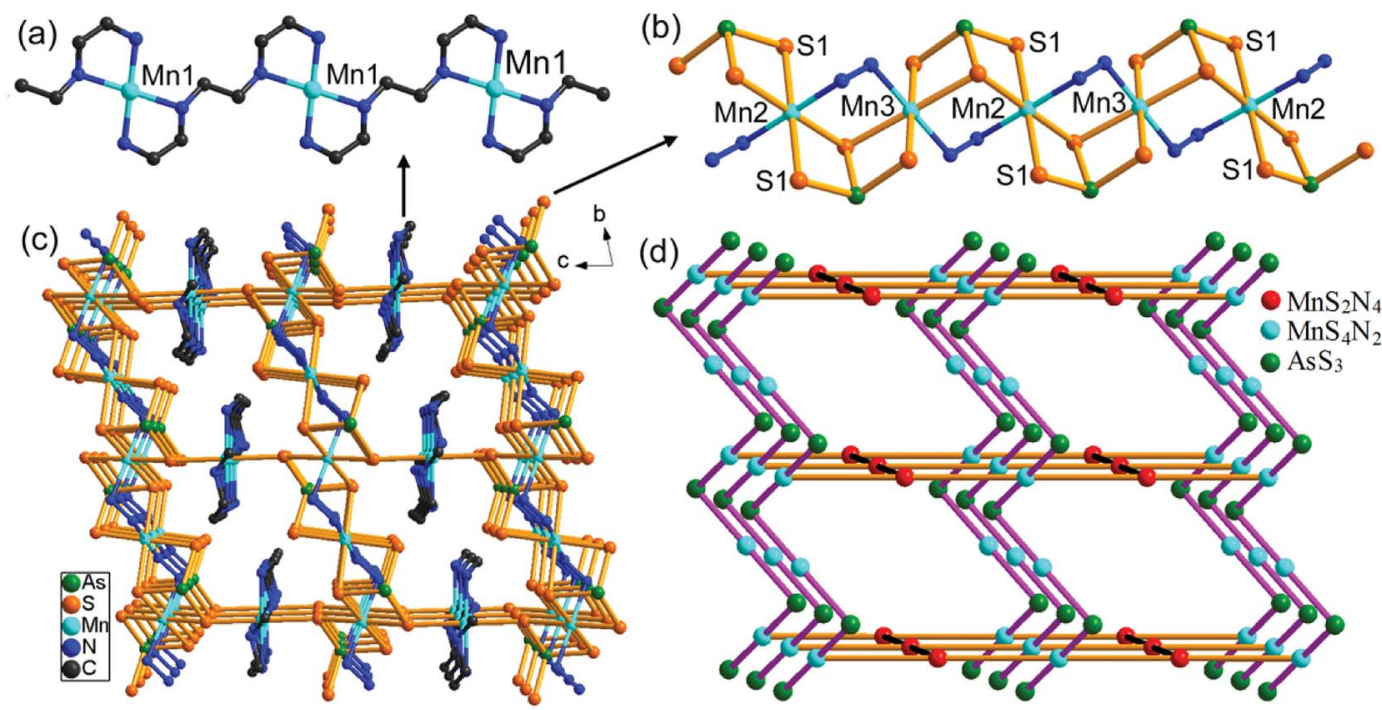

Fig. 5 Crystal structures for compound 3: (a) planar $\left[\{\mathrm{Mn}(\mu \text {-trien })\}^{2+}\right]_{n}$ cationic chain. (b) $\left[\mathrm{Mn}_{2}\left\{\left(\mu-\mathrm{N}_{2} \mathrm{H}_{4}\right)\left(\mu_{3}-\mathrm{AsS}_{3}\right)\right\}_{2}{ }^{2-}\right]_{n}$ anionic chain (hydrogen atoms are omitted for clarity). (c) Packing diagram of 3-D $\left[\mathrm{Mn}\left(\mu \text {-trien) }\left(\mathrm{Mn}_{2}\left\{\left(\mu-\mathrm{N}_{2} \mathrm{H}_{4}\right)\left(\mu-\mathrm{AsS}_{3}\right)\right\}_{2}\right)\right]_{n}\right.$ framework. (d) Schematic depiction of the 3-D framework in 3 .

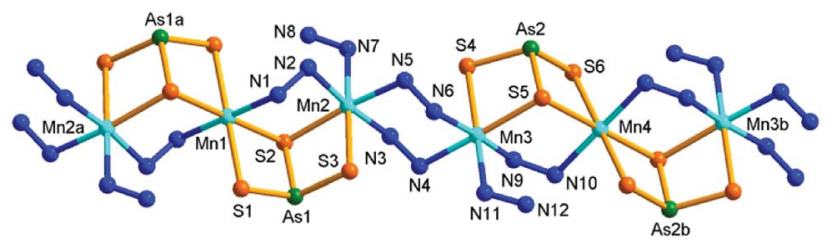

Fig. 6 Structure of 4 with the labeling scheme. Hydrogen atoms are omitted for clarity. Symmetry codes: (a) $-x,-y+1,-z+2$; (b) $-x+1$, $-y+3,-z+1$

The layers are further connected by the $\mathrm{N}-\mathrm{H} \cdots \mathrm{S}$ hydrogen bonds into a 3D frame work (Fig. S13†).

Compound 5 crystallizes in the monoclinic space group $P 2 / n$ with two formulae in the unit cell. There are one and a half crystallographically independent $\mathrm{Mn}$, two halves As, and four S atoms (Fig. 7a). As(1) ${ }^{3+}$ and $\mathrm{As}(2)^{3+}$ ions are both coordinated with four $\mathrm{S}^{2-}$ anions to form tetrahedral $\mathrm{AsS}_{4}$ units. $\mathrm{Mn}(1)^{2+}$ is coordinated by four $\mathrm{N}$ atoms from four $\mu-\mathrm{N}_{2} \mathrm{H}_{4}$ bridging ligands and two $\mathrm{S}$ atoms of two $\mathrm{AsS}_{4}$ units, while $\mathrm{Mn}(2)^{2+}$ ion is coordinated by four $\mathrm{N}$ atoms from four $\mu-\mathrm{N}_{2} \mathrm{H}_{4}$ bridging ligands and is chelated by two $\mathrm{S}$ atoms of the $\mathrm{As}_{(1) \mathrm{S}_{4}}$ unit. Both $\mathrm{Mn}(1)$ and $\mathrm{Mn}$ (2) form distorted octahedra $\mathrm{MnN}_{4} \mathrm{~S}_{2}$. The As-S, Mn-S, and $\mathrm{Mn}-\mathrm{N}$ bond lengths are in the range of the corresponding bond lengths in the $\mathrm{Mn}(\mathrm{II})$-thioarsenate(v) of 2 (Tables S3 and S6 $†$ ). In $5, \operatorname{Mn}(1)$ and $\operatorname{Mn}(2)$ are connected by six $\mu-\mathrm{N}_{2} \mathrm{H}_{4}$ bridging ligands into a infinite $\left[\mathrm{Mn}_{3}\left(\mathrm{~N}_{2} \mathrm{H}_{4}\right)_{6}\right]_{n}$ chain. The As(1) $\mathrm{S}_{4}$ unit bridges $\operatorname{Mn}(1)$ and $\operatorname{Mn}(2)$ centers with a $\mu_{3}-1 \kappa S^{1}: 2 \kappa^{2} S^{1}, S^{2}: 3 \kappa S^{2}$ bridging mode, forming a $\left[\mathrm{Mn}_{3}\left(\mu-\mathrm{N}_{2} \mathrm{H}_{4}\right)_{6}\left(\mu_{3}-\mathrm{AsS}_{4}\right)^{3+}\right]_{n}$ cationic chain (Fig. 7b). The cationic chains are linked by the $\left[\operatorname{As}(2) \mathrm{S}_{4}\right]^{3-}$ unit at $\mathrm{Mn}(1)$ to form the neutral $\left[\mathrm{Mn}_{3}\left(\mu-\mathrm{N}_{2} \mathrm{H}_{4}\right)_{6}\left(\mu_{3}-\mathrm{AsS}_{4}\right)\left(\mu_{2}-\right.\right.$ $\left.\left.\mathrm{AsS}_{4}\right)\right]_{n}$ layer perpendicular to the $b$ axis (Fig. 7c). The As(2)S unit adopts a bidentate $\mu-1 \kappa S^{1}: 2 \kappa S^{2}$ bridging mode. Large circle $\left[\left\{\mathrm{Mn}_{4}\left(\mu-\mathrm{N}_{2} \mathrm{H}_{4}\right)_{3}\right\}_{2}\left(\mu_{2}-\mathrm{AsS}_{4}\right)_{2}\right]$ is formed in the layer. It is built up from eight $\mathrm{Mn}^{2+}$ ions joined by twelve $\mu-\mathrm{N}_{2} \mathrm{H}_{4}$ and two $\mu$-AsS ${ }_{4}$ bridges (Fig. 7d). The $\left[\mathrm{Mn}_{3}\left(\mu-\mathrm{N}_{2} \mathrm{H}_{4}\right)_{6}\left(\mu_{3}-\mathrm{AsS}_{4}\right)\left(\mu_{2}-\mathrm{AsS}_{4}\right)\right]_{n}$ layers run parallel to the (101) plane, and interact with each other via intermolecular $\mathrm{N}-\mathrm{H} \cdots \mathrm{S}$ hydrogen bonds (Table S8†), forming a 3D framework (Fig. S14 and S15†).

Compound 6 crystallizes in the triclinic space group $P \overline{1}$. The $\mathrm{As}^{5+}$ ion is coordinated with four $\mathrm{S}^{2-}$ anions, forming an $\mathrm{AsS}_{4}$ tetrahedron. The $\mathrm{Mn}(1)^{2+}$ ion binds a $\mathrm{NH}_{3}$ molecule forming $\mathrm{a}\left[\mathrm{Mn}\left(\mathrm{NH}_{3}\right)\right]^{2+}$ unit. The $\left[\mathrm{Mn}\left(\mathrm{NH}_{3}\right)\right]^{2+}$ units are joined by the $\mathrm{AsS}_{4}$ tetrahedra into a $\left[\left\{\mathrm{Mn}\left(\mathrm{NH}_{3}\right)\left(\mu_{3}-\mathrm{AsS}_{4}\right)\right\}_{2}{ }^{2-}\right]_{n}$ anionic chain (Fig. 8). The $\mathrm{AsS}_{4}$ tetrahedron acts as tridentate ligand in $\mu_{3}$ $1 \kappa^{2} S^{1}, S^{2}: 2 \kappa^{2} S^{1}, S^{3}: 3 \kappa S^{1}$ bridging mode. The $\mathrm{Mn}(1)^{2+}$ ion lies in an octahedral geometry involved in five $\mathrm{S}$ atoms from three $\mathrm{AsS}_{4}$ tetrahedra and a $\mathrm{NH}_{3}$ molecule. The As-S and $\mathrm{Mn}-\mathrm{S}$ bond lengths are consistent with the corresponding bond lengths found in 5 (Tables S6 and S7†). The $\operatorname{Mn}(2)^{2+}$ ion is coordinated by six $\mathrm{NH}_{3}$ molecules to form a $\left[\mathrm{Mn}\left(\mathrm{NH}_{3}\right)_{6}\right]^{2+}$ complex cation. The $\left[\left\{\mathrm{Mn}\left(\mathrm{NH}_{3}\right)\left(\mu_{3}-\mathrm{AsS}_{4}\right)\right\}_{2}{ }^{2-}\right]_{n}$ chains run parallel along the $a$ axis. The $\left[\mathrm{Mn}\left(\mathrm{NH}_{3}\right)_{6}\right]^{2+}$ complex cations are located between the chains, and interact with the anionic chains with $\mathrm{N}-\mathrm{H} \cdots \mathrm{S}$ hydrogen bonds (Fig. S16†).

In compounds 1-6, the $\mathrm{AsS}_{3}$ and $\mathrm{AsS}_{4}$ units coordinate to the $\mathrm{Mn}$ (II) centers in different bridging coordination modes, which are summarily illustrated in Fig. 9. As shown in Fig. 9, all $\mathrm{S}$ atoms of the $\mathrm{AsS}_{3}$ trigonal pyramid take part in coordination to the $\mathrm{Mn}$ (II) center (Fig. 9a-c). The $\mathrm{AsS}_{3}$ unit chelates two $\mathrm{Mn}^{2+}$ ions in a $\mu_{2}-1 \kappa^{2} S^{1}, S^{2}: 2 \kappa^{2} S^{1}, S^{3}$ mode in compound 4 (Fig. 9c). It acts as a $\mu_{3}-\mathrm{AsS}_{3}$ bridging ligand with a $\mu_{3}$ $1 \kappa^{2} S^{1}, S^{2}: 2 \kappa^{2} S^{1}, S^{3}: 2 \kappa^{2} S^{2}, S^{3}$ mode in compound 1 (Fig. 9a), and a $\mu_{3}-1 \kappa^{1} S^{1}: 2 \kappa^{2} S^{1}, S^{2}: 2 \kappa^{2} S^{2}, S^{3}$ mode in compound 3 (Fig. 9b), to join three different $\mathrm{Mn}^{2+}$ ions. The tetrahedral $\mathrm{AsS}_{4}$ unit can bind Mn(II) center with one, two or three S atoms (Fig. 9d-g). The $\mathrm{AsS}_{4}$ unit adopts a terminal mode with one $\mathrm{S}$ atom to join two Mn(II) centers in compound 2 (Fig. 9d). It links two Mn(II) centers with a $\mu-1 \kappa^{1} S^{1}: 2 \kappa^{1} S^{2}$ mode (Fig. 9e), and three $\mathrm{Mn}(\mathrm{II})$ 

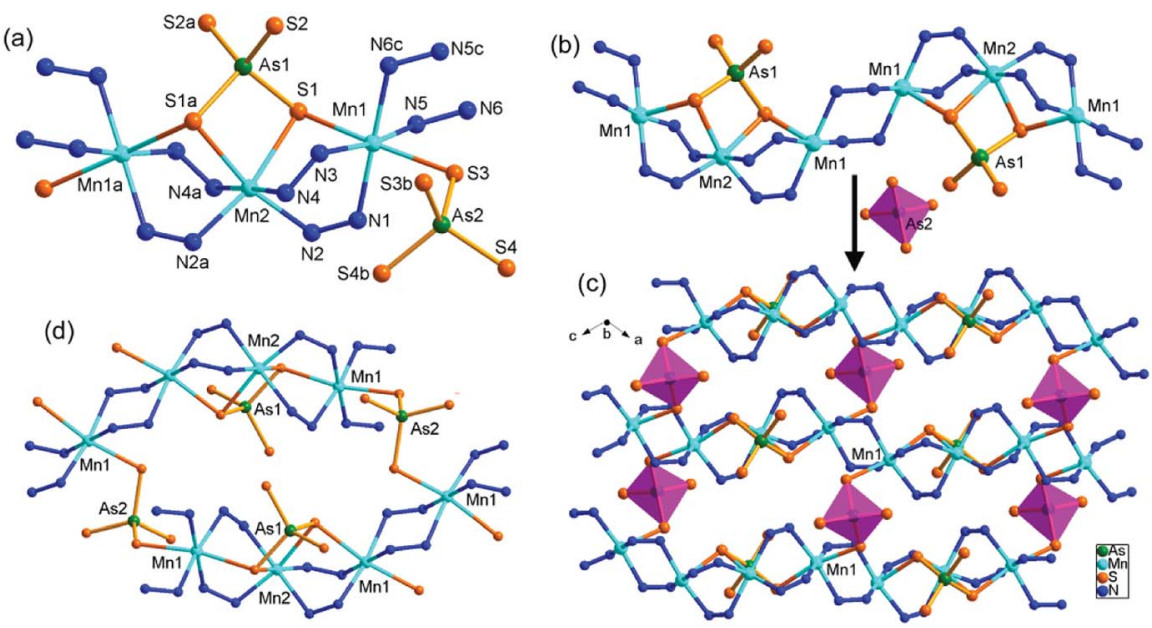

Fig. 7 (a) The asymmetric structural unit of 5 with the labeling scheme, showing coordination environments of each $\mathrm{Mn}^{2+}$ ion. Hydrogen atoms are omitted for clarity. Symmetry codes: (a) $-x+1 / 2, y,-z+3 / 2$; (b) $-x+1 / 2, y,-z+5 / 2$; (c) $-x,-y+2$, $-z+2$. (b) The $\left[\mathrm{Mn}_{3}\left(\mu-\mathrm{N}_{2} \mathrm{H}_{4}\right)_{6}\left(\mu_{3}-\right.\right.$ $\left.\left.\mathrm{AsS}_{4}\right)^{3+}\right]_{n}$ chain. (c) The layer constructed by the $\left[\mathrm{Mn}_{3}\left(\mu-\mathrm{N}_{2} \mathrm{H}_{4}\right)_{6}\left(\mu_{3}-\mathrm{AsS}_{4}\right)^{3+}\right]_{n}$ chains and $\mu_{2}-\mathrm{AsS}_{4}$ tetrahedral linkers. $(\mathrm{d}) \mathrm{The}\left[\mathrm{Mn}_{4}\left(\mu-\mathrm{N}_{2} \mathrm{H}_{4}\right)_{3}\right\}_{2}\left(\mu_{2}-\right.$ $\left.\mathrm{AsS}_{4}\right)_{2}$ ] circle in 5 . Hydrogen atoms are omitted for clarity.

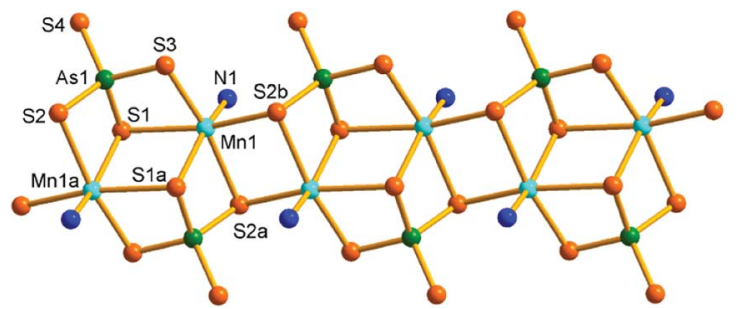

Fig. 8 Structure of the $\left[\left\{\mathrm{Mn}\left(\mathrm{NH}_{3}\right)\left(\mu_{3}-\mathrm{AsS}_{4}\right)\right\}_{2}{ }^{2-}\right]_{n}$ anionic chain in 6 with the labeling scheme. Hydrogen atoms are omitted for clarity. Symmetry codes: (a) $-x,-y+1,-z+1$; (b) $-x+1,-y+1,-z+1$.

centers with a $\mu_{3}-1 \kappa S^{1}: 2 \kappa^{2} S^{1}, S^{2}: 3 \kappa S^{2}$ mode in compound 5 (Fig. 9g). The $\mathrm{AsS}_{4}$ unit in 6 joins three Mn(II) centers with a $\mu_{3}$ $1 \kappa^{1} S^{1}: 2 \kappa^{2} S^{1}, S^{2}: 2 \kappa^{2} S^{2}, S^{3}$ mode (Fig. 9f), which is in the same coordination mode with the $\mathrm{AsS}_{3}$ unit in compound 3

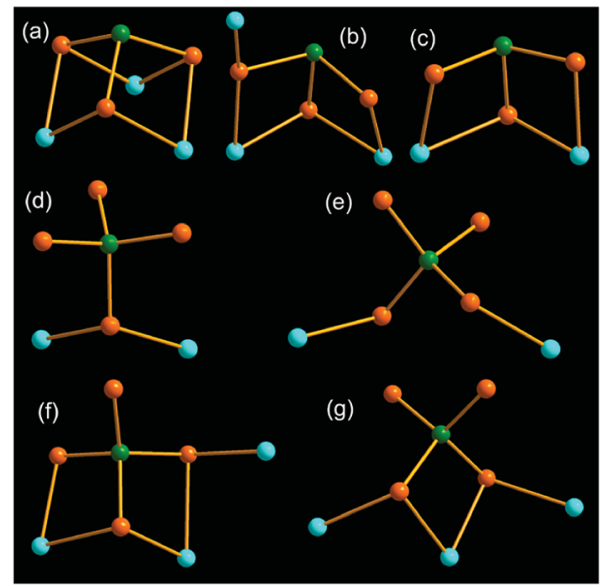

Fig. 9 Coordination modes of the $\mathrm{AsS}_{3}$ and $\mathrm{AsS}_{4}$ units to $\mathrm{Mn}($ (I) centers in compounds 1 (a), 2 (d), 3 (b), 4 (c), 5 (e, g), 6 (f). The As, S and Mn atoms are drawn as green, orange and cyan spheres.
(Fig. 9b). Different modes $\mu_{2}-1 \kappa^{2} S^{1}, S^{2}: 2 \kappa^{2} S^{1}, S^{3}, \quad \mu_{3}$ $1 \kappa^{2} S^{1}, S^{2}: 2 \kappa^{2} S^{2}, S^{3}: 2 \kappa^{2} S^{3}, S^{4}$ and $\mu_{3}-1 \kappa^{1} S^{1}: 2 \kappa^{2} S^{1}, S^{2}: 2 \kappa^{1} S^{3}$ for the $\mathrm{AsS}_{4}$ unit are observed in compounds $\left[\mathrm{NH}_{4}\right]_{8}\left[\mathrm{Mn}_{2}\left(\mathrm{AsS}_{4}\right)_{4}\right],{ }^{14 a}$ $\left[\mathrm{Mn}_{3} \mathrm{~L}_{3}\left(\mathrm{AsS}_{4}\right)_{2}\right] \cdot \mathrm{H}_{2} \mathrm{O}\left(\mathrm{L}=2,2^{\prime}\right.$-bipy, phen $),{ }^{9 b, 24}$ and $[\mathrm{Mn}(1,2-$ dap $\left.)_{2}\right]\left\{[\mathrm{Mn}(1,2 \text {-dap })]_{2}\left(\mathrm{AsS}_{4}\right)_{2}\right\},{ }^{21 c}$ respectively.

\section{Optical properties}

The solid state near-IR/UV-Vis reflectance spectra of compounds 1-6 above were measured at room temperature on powder samples. The reflectance spectra were converted to optical absorption data by the Kubelka-Munk function, ${ }^{24}$ which are shown in Fig. 10. The band gaps can be estimated from the steep absorption edge at 2.32 (1), 2.44 (2), 2.19 (3), 2.39 (4), 2.35 (5), and $2.47(6) \mathrm{eV}$, which are in accordance with their colors, respectively. The band gaps of $\mathbf{2 , 4}$ and $\mathbf{6}$ are comparable to that of the $\mathrm{Mn}(\mathrm{II})$-thioarsenates $\left[\mathrm{Mn}\left(\mathrm{NH}_{3}\right)_{6}\right]\left[\left(\mathrm{N}_{2} \mathrm{H}_{4}\right)_{2} \mathrm{Mn}_{2} \mathrm{As}_{2} \mathrm{~S}_{8}\right]\left(E_{\mathrm{g}}=\right.$ $2.46 \mathrm{eV}){ }^{14 a}$ Compounds 1-6 exhibit a blue shift compared with

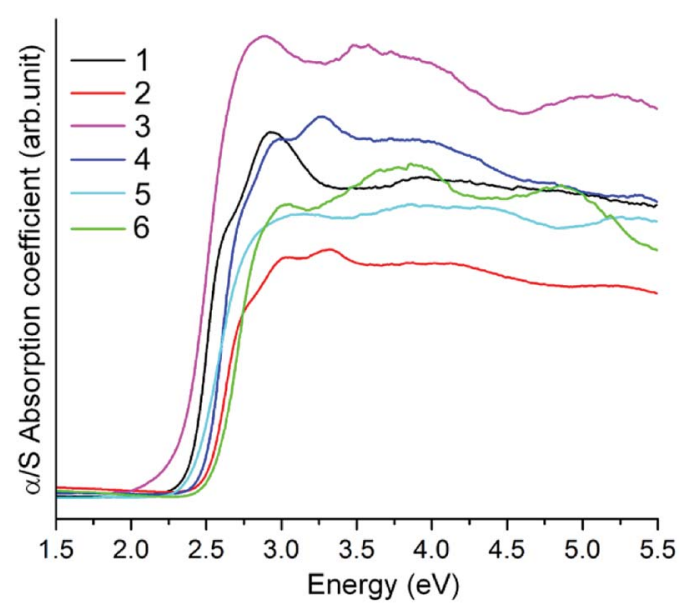

Fig. 10 Solid state optical absorption spectra of compounds 1-6. 
those of polymeric $\mathrm{Mn}(\mathrm{II})$-thioarsenates $\left[\mathrm{Mn}_{2}(\mathrm{phen})\left(\mathrm{As}_{2} \mathrm{~S}_{5}\right)\right]_{n}\left(E_{\mathrm{g}}\right.$ $=2.01 \mathrm{eV})$ and $\left[\mathrm{Mn}_{3}(\text { phen })_{3}\left(\mathrm{AsS}_{4}\right)_{2}\right]_{n} \cdot \mathrm{nH}_{2} \mathrm{O}\left(E_{\mathrm{g}}=1.97 \mathrm{eV}\right)$ decorated by rigid amine phen (phen $=1,10$-phenanthroline). ${ }^{25}$

\section{Magnetic properties}

The magnetic susceptibilities of $\mathbf{1}$ and $\mathbf{2}$ were investigated for polycrystalline samples in the temperature range of $2-300 \mathrm{~K}$ under an applied field of 1000 Oe. Temperature dependence of $\chi_{\mathrm{m}}$ and $\chi_{\mathrm{m}} T$ ( $\chi_{\mathrm{m}}$ is the magnetic susceptibility per $\mathrm{Mn}$ (II) ion) curves for compounds 1 and 2 are shown in Fig. 11. For compound 1, the $\chi_{\mathrm{m}} T$ value is equal to $3.82 \mathrm{~cm}^{3} \mathrm{~K} \mathrm{~mol}^{-1}$ at 300 $\mathrm{K}$, which is smaller than the spin-only value $\left(4.375 \mathrm{~cm}^{3} \mathrm{~K} \mathrm{~mol}^{-1}\right)$ for a single high-spin $\mathrm{Mn}$ (II) ion, indicating strong antiferromagnetic $(\mathrm{AF})$ exchange interactions in 1. The diamagnetic bridges $\mu_{2}-\mathrm{S}$ and $\mu_{2}-\mathrm{NH}_{2} \mathrm{NH}_{2}$ between the $\mathrm{Mn}$ (II) ions give rise to the superexchange magnetic interactions, as observed in the chalcogenides $\mathrm{Ba}_{2} \mathrm{MnS}_{3},{ }^{26}\left[\mathrm{Mn}_{2}\left(2,2^{\prime}\right.\right.$-bipy $\left.) \mathrm{As}_{2} \mathrm{~S}_{5}\right],{ }^{9 \boldsymbol{b}}$ and $\left[\mathrm{Mn}_{2}(-\right.$ $\left.\left.\mathrm{NH}_{2} \mathrm{NH}_{2}\right)_{2} \mathrm{SnS}_{4}\right]{ }^{17 a}$ When the temperature is lowered, the $\chi_{\mathrm{m}} T$ value decreases gradually and reaches a value of $0.074 \mathrm{~cm}^{3}$ $\mathrm{mol}^{-1} \mathrm{~K}$ at $2 \mathrm{~K}$. Meanwhile, the magnetic susceptibility $\left(\chi_{\mathrm{m}}\right)$ increases with lowering temperature until $\chi_{\mathrm{m}}$ reaches a maximum value of $0.0380 \mathrm{~mol} \mathrm{~cm} \mathrm{~cm}^{-3}$ and then decreases gradually, which exhibits antiferromagnetic ordered state with Néel temperature of $26 \mathrm{~K}$. The $1 / \chi_{\mathrm{m}} v s$. T curve in the temperature range 100-300 K obeys the Curie-Weiss law with $C=5.42$ $\mathrm{cm}^{3} \mathrm{~K} \mathrm{~mol}^{-1}$ and $\theta=-126.45 \mathrm{~K}$ (Fig. S17 $\dagger$ ). The large negative $\theta$ value further confirms the strong AF interactions among the $\mathrm{Mn}$ (II) ions in compound 1. The triangular arrangement of the $\mathrm{Mn}$ (II) ions can induce spin frustration in $\mathbf{1}$. The parameter,
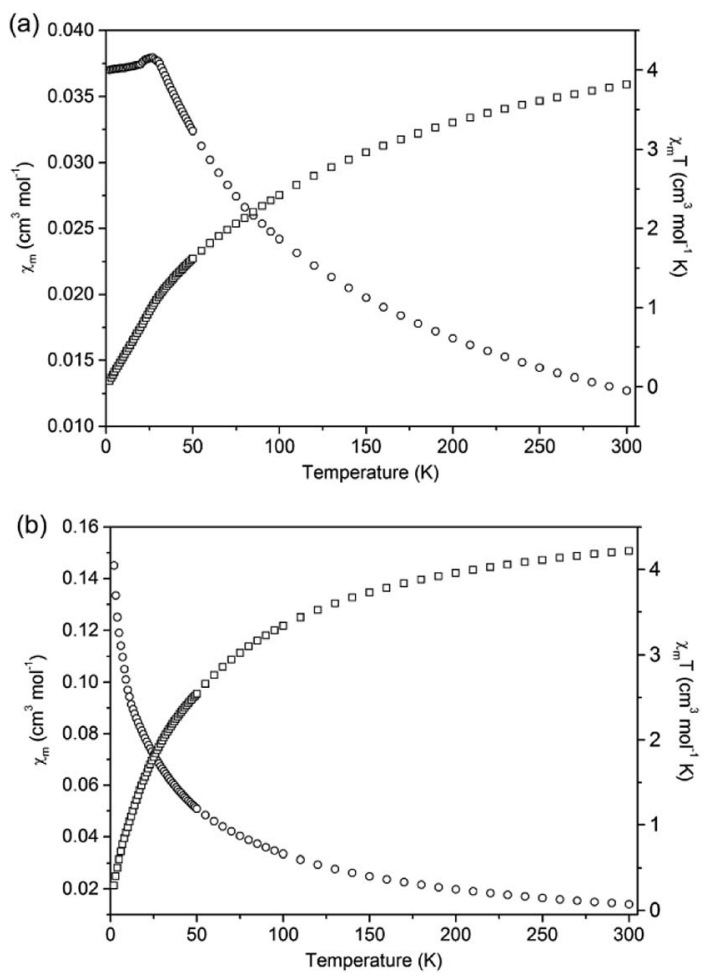

Fig. 11 Curves of $\chi_{m} T$ and $\chi_{m}$ versus $T$ for compounds 1 (a) and 2 (b). which is defined as $f=|\theta| / T_{\mathrm{N}}$, is widely used to measure the relative degree of the spin frustration. The $f$ value of 4.86 indicates weak spin-frustration in $\mathbf{1}$.

At $300 \mathrm{~K}$, the $\chi_{\mathrm{m}} T$ value of compound 2 is equal to $4.22 \mathrm{~cm}^{3} \mathrm{~K}$ $\mathrm{mol}^{-1}$ in agreement with the spin-only value $\left(4.375 \mathrm{~cm}^{3} \mathrm{~K}\right.$ $\mathrm{mol}^{-1}$ ) for a single high-spin $\mathrm{Mn}$ (II) ion. When the temperature is lowered, the $\chi_{\mathrm{m}} T$ value decreases gradually and reaches a value of $0.31 \mathrm{~cm}^{3} \mathrm{~mol}^{-1} \mathrm{~K}$ at $2 \mathrm{~K}$. Meanwhile, $\chi_{\mathrm{m}}$ continuously increases from $0.0141 \mathrm{~cm}^{3} \mathrm{~mol}^{-1}$ to a value of $0.155 \mathrm{~cm}^{3} \mathrm{~mol}^{-1}$ at $2 \mathrm{~K}$. The $1 / \chi_{\mathrm{m}} v s . T$ curve in the temperature range $50-300 \mathrm{~K}$ obeys the Curie-Weiss law with $C=4.51 \mathrm{~cm}^{3} \mathrm{~K} \mathrm{~mol}^{-1}$ and $\theta=$ $-19.85 \mathrm{~K}$ (Fig. S18†). The negative $\theta$ value confirms the weak antiferromagnetic interactions among the $\mathrm{Mn}$ (II) ions. The calculated effective magnetic moment $\left(\mu_{\text {eff }}\right)$ for one $\mathrm{Mn}$ (II) ion in compound 2 is $5.81 \mu_{\mathrm{B}}$ (Fig. S18 $\dagger$ ), which is close to the expected spin-only value of a free $\mathrm{Mn}$ (II) ion $\left(5.92 \mu_{\mathrm{B}}\right)$. It is worthy to note that the negative Weiss constant of $\mathbf{1}$ is larger than that of 2 . Besides the more $\mathrm{Mn}-\mathrm{S}-\mathrm{Mn}$ superexchange magnetic interactions in 1, the shorter $\mathrm{Mn}$ (II) $\cdots \mathrm{Mn}$ (II) distance in $\mathbf{1}$ aids the $\mathrm{AF}$ exchange interactions. ${ }^{9 \boldsymbol{d}}$ The distances between adjacent $\mathrm{Mn}$ (II) ions in 2 are $3.774 \AA$ and $6.458 \AA$ based on crystal structure. Whilst, compound 1 contains shorter $\mathrm{Mn}$ (II) $\cdots \mathrm{Mn}$ (II) distances in the range of 3.568-3.792 $\AA$, causing a stronger AF coupling interaction in $\mathbf{1}$.

\section{Experimental}

\section{Materials and methods}

All starting chemicals except $\mathrm{N}_{2} \mathrm{H}_{4} \cdot \mathrm{H}_{2} \mathrm{O}$ are of analytical grade and were used as received. $\mathrm{N}_{2} \mathrm{H}_{4} \cdot \mathrm{H}_{2} \mathrm{O}$ is $98 \%$ aqueous solution. Elemental analyses were conducted using an EA1110-CHNS-O elemental analyzer. Powder X-ray diffraction (PXRD) patterns were collected on a D/MAX-3C diffractometer using graphite monochromatized $\mathrm{CuK} \alpha$ radiation $(\lambda=1.5406 \AA)$. Fourier infrared (FT-IR) spectra were recorded on a Nicolet Magna-IR 550 spectrometer using dry $\mathrm{KBr}$ discs over the $4000-400 \mathrm{~cm}^{-1}$ range. Room-temperature optical diffuse reflectance spectra of powder samples were obtained using a Shimadzu UV-3150 spectrometer. Absorption $(\alpha / S)$ data were calculated from reflectance using the Kubelka-Munk function $\alpha / S=(1-R)^{2} / 2 R$, where $R$ is the reflectance at a given energy, $\alpha$ is the absorption, and $S$ is the scattering coefficient. ${ }^{24}$ Magnetic susceptibility measurements were performed with a Quantum Design MPMSXL SQUID susceptometer in the temperature range 2-300 K under an applied field of 1000 Oe. The magnetic data were corrected for the sample holder and the diamagnetic contributions. Thermogravimetric analysis was conducted on a SDT 2960 microanalyzer and the samples were heated at a rate of $5{ }^{\circ} \mathrm{C} \mathrm{min}{ }^{-1}$ under a nitrogen stream of $100 \mathrm{~mL} \mathrm{~min}^{-1}$.

\section{Syntheses of 1-6}

$\left[\mathrm{Mn}(\mathrm{en})_{3}\right]_{n}\left[\left(\mathbf{N}_{2} \mathbf{H}_{4}\right)_{2} \mathbf{M n}_{6}\left(\mu_{6}-\mathbf{S}\right)\left(\mu-\mathbf{N}_{2} \mathbf{H}_{4}\right)_{2}\left(\mu_{3}-\mathrm{AsS}_{3}\right)_{4}\right]_{n} \quad$ (1). Mn (55.0 mg, $1.0 \mathrm{mmol}$ ), As (37.5 mg, $0.50 \mathrm{mmol}), \mathrm{S}(64.1 \mathrm{mg}, 2.0$ $\mathrm{mmol}$ ), ethylenediamine (en, $1.0 \mathrm{~mL}$ ), and hydrazine monohydrate $(98 \%, 1.0 \mathrm{~mL})$ were mixed by stirring for 10 minutes, and then the mixture was loaded into a polytetrafluoroethylene 
(PTFE)-lined stainless steel autoclave of volume $10 \mathrm{~mL}$. NOTE: hydrazine is highly toxic and explosive, and should be handled carefully. The sealed autoclave was heated to $110{ }^{\circ} \mathrm{C}$ for 6 days and then cooled to ambient temperature. The crude product contains yellow crystals and black powder. The crude product was transferred into a vial which was filled with en $/ \mathrm{C}_{2} \mathrm{H}_{5} \mathrm{OH}$ $(1: 1(\mathrm{~V} / \mathrm{V}))$. Most of the black powder was suspended in the solution, which was then decanted leaving behind crystals. This procedure was repeated until the water remained clear. Then, the resulting yellow block crystals of 1 were filtered off, washed with ethanol, and stored under vacuum. Yield $72 \mathrm{mg}(41 \%$ based on As). Elemental analysis calcd for $\mathrm{C}_{6} \mathrm{H}_{40} \mathrm{~N}_{14} \mathrm{~S}_{13} \mathrm{Mn}_{7} \mathrm{As}_{4}$ (1): C, 5.11; H, 2.86; N, 13.91. Found: C, 4.95; H, 2.82; N, 13.78\%. IR data (KBr, cm $\left.{ }^{-1}\right): 3449(\mathrm{~m}), 3252(\mathrm{w}), 3139(\mathrm{w}), 2946(\mathrm{w}), 2864$ (w), 2085 (w), 1636 (s), 1583 (s), 1480 (s), 1379 (w), 1304 (m), 1190 (w), $1123(\mathrm{w}), 1077(\mathrm{w}), 986(\mathrm{w}), 949(\mathrm{w}), 880(\mathrm{w}), 816(\mathrm{w}), 669(\mathrm{w})$, $619(\mathrm{w}), 591(\mathrm{w}), 458(\mathrm{w}), 431(\mathrm{w})$.

$\left[\mathbf{N}_{2} \mathbf{H}_{5}\right]_{n}\left[\left\{\mathbf{M n}\left(\mu-\mathbf{N}_{2} \mathbf{H}_{4}\right)_{2}\left(\mu-A_{s} S_{4}\right)\right\} \cdot 0.5 e n\right]_{n}(2) . M n(55.0 \mathrm{mg}, 1.0$ $\mathrm{mmol}$ ), As (37.5 mg, $0.50 \mathrm{mmol}), \mathrm{S}(64.1 \mathrm{mg}, 2.00 \mathrm{mmol})$, en (0.5 $\mathrm{mL})$, and hydrazine monohydrate $(98 \%, 1.5 \mathrm{~mL})$ were mixed by stirring for 10 minutes, and then the mixture was loaded into a PTFE-lined stainless steel autoclave of volume $10 \mathrm{~mL}$. The sealed autoclave was heated to $90{ }^{\circ} \mathrm{C}$ for 6 days and then cooled to ambient temperature. The yellow block crystals of 2 were collected with a procedure similar to that for the treatment of $\mathbf{1}$. Yield $99 \mathrm{mg}$ (52\% based on As). Elemental analysis calcd for $\mathrm{CH}_{17} \mathrm{~N}_{7} \mathrm{~S}_{4} \mathrm{MnAs}$ (2): calcd C, 3.12; H, 4.45; N, 25.45. Found: C, 2.98; H, 4.32; N, 25.29\%. IR data $\left(\mathrm{KBr}, \mathrm{cm}^{-1}\right)$ : 3414 (s), $3039(\mathrm{w})$, 2926 (w), 2388 (w), 2131 (w), 1626 (m), 1509 (w), 1425 (s), 1379 (w), 1341 (w), 1202 (w), 1109 (s), 996 (m), 845 (s), 769 (w), 719 (s), $677(\mathrm{w}), 622(\mathrm{w}), 471(\mathrm{w}), 441(\mathrm{w}), 412(\mathrm{w})$.

$\left[\mathbf{M n}(\mu \text {-trien })\left\{\mathbf{M n}\left(\mu-\mathbf{N}_{2} \mathbf{H}_{4}\right)\left(\mu-\mathbf{A s S}_{3}\right)\right\}_{2}\right]_{n}$ (3). Mn (55.0 mg, 1.0 $\mathrm{mmol})$, As (37.5 mg, $0.50 \mathrm{mmol}), \mathrm{S}(64.1 \mathrm{mg}, 2.00 \mathrm{mmol})$, triethylenetetramine (trien, $1.0 \mathrm{~mL}$ ), and hydrazine monohydrate $(98 \%, 1.0 \mathrm{~mL})$ were mixed by stirring for 10 minutes, and then the mixture was loaded into a PTFE-lined stainless steel autoclave of volume $10 \mathrm{~mL}$. The sealed autoclave was heated to $110^{\circ} \mathrm{C}$ for 6 days and then cooled to ambient temperature. The orange block crystals of 3 were collected with a procedure similar to that for the treatment of 1 . Yield $86 \mathrm{mg}$ ( $48 \%$ based on As). Elemental analysis calcd for $\mathrm{C}_{6} \mathrm{H}_{26} \mathrm{~N}_{8} \mathrm{~S}_{6} \mathrm{Mn}_{3} \mathrm{As}_{2}$ (3): calcd C, 10.05; H, 3.65; N, 15.62. Found: C, 9.89; H, 3.45; N, 15.48\%. IR data $\left(\mathrm{KBr}, \mathrm{cm}^{-1}\right)$ : $3411(\mathrm{~s}), 2931$ (w), $2844(\mathrm{w}), 2116(\mathrm{w}), 1780$ (w),1654 (s), 1587 (s), 1474 (m), 1379 (w), 1314 (m), 1194 (w), $1123(\mathrm{w}), 1073(\mathrm{w}), 991(\mathrm{w}), 869(\mathrm{w}), 808(\mathrm{w}), 771(\mathrm{w}), 657(\mathrm{w}), 619$ (m), $594(\mathrm{w}), 499(\mathrm{w}), 427(\mathrm{w}) \mathrm{cm}^{-1}$.

$\left[\left\{\mathbf{M n}\left(\mathbf{N}_{2} \mathbf{H}_{4}\right)\right\}_{2}\left(\mu-\mathbf{N}_{2} \mathbf{H}_{4}\right)_{2}\left\{\mathbf{M n}\left(\mu-\mathbf{N}_{2} \mathbf{H}_{4}\right)_{2}\left(\mu-\mathbf{A s S}_{3}\right)_{2}\right\}\right]_{n} \quad$ (4). $\quad \mathrm{Mn}$ (55.0 mg, $1.0 \mathrm{mmol}$ ), As (37.5 mg, $0.50 \mathrm{mmol}), \mathrm{S}(64.1 \mathrm{mg}, 2.00$ $\mathrm{mmol})$, trien $(0.5 \mathrm{~mL})$, hydrazine monohydrate $(98 \%, 1.0 \mathrm{~mL})$, and DMF $(0.5 \mathrm{~mL})$ were mixed by stirring for 10 minutes, and then the mixture was loaded into a PTFE-lined stainless steel autoclave of volume $10 \mathrm{~mL}$. The sealed autoclave was heated to $90{ }^{\circ} \mathrm{C}$ for 6 days and then cooled to ambient temperature. The yellow block crystals of $\mathbf{4}$ were collected with a procedure similar to that for the treatment of 1 . Yield $93 \mathrm{mg}$ ( $53 \%$ based on As). Elemental analysis calcd for $\mathrm{H}_{24} \mathrm{~N}_{12} \mathrm{~S}_{6} \mathrm{Mn}_{3} \mathrm{As}_{2}$ (4): calcd $\mathrm{H}$, 3.46; N, 24.04. Found: H, 3.32; N, 23.92\%. IR data $\left(\mathrm{KBr}, \mathrm{cm}^{-1}\right)$ :
3283 (m), 3101 (w), 1631 (m), 1595 (m), 1484 (w), 1425 (w), 1379 (w), 1345 (w), 1152 (s), 1120 (s), 992 (m), 953 (w), $870(\mathrm{w}), 668$ (m), $597(\mathrm{w}), 496(\mathrm{w}), 433(\mathrm{w}), 411(\mathrm{~m}) \mathrm{cm}^{-1}$.

$\left[\mathbf{M n}_{3}\left(\boldsymbol{\mu}-\mathbf{N}_{2} \mathbf{H}_{4}\right)_{\mathbf{6}}\left(\mathbf{A s S}_{4}\right)\left(\boldsymbol{\mu}-\mathbf{A s S}_{4}\right)\right]_{\boldsymbol{n}}(\mathbf{5}) . \mathrm{Mn}(55.0 \mathrm{mg}, 1.0 \mathrm{mmol})$, As $(37.5 \mathrm{mg}, 0.50 \mathrm{mmol}), \mathrm{S}(64.1 \mathrm{mg}, 2.00 \mathrm{mmol})$, hydrazine monohydrate $(98 \%, 1.5 \mathrm{~mL})$, and DMF $(0.5 \mathrm{~mL})$ were mixed by stirring for 10 minutes, and then the mixture was loaded into a PTFE-lined stainless steel autoclave of volume $10 \mathrm{~mL}$. The sealed autoclave was heated to $90{ }^{\circ} \mathrm{C}$ for 6 days and then cooled to ambient temperature. The yellow block crystals of 5 were collected with a procedure similar to that for the treatment of $\mathbf{1}$. Yield $88 \mathrm{mg}$ (46\% based on As). Elemental analysis calcd for $\mathrm{H}_{24} \mathrm{~N}_{12} \mathrm{~S}_{8} \mathrm{Mn}_{3} \mathrm{As}_{2}$ (5): calcd H, 3.17; N, 22.02. Found: H, 3.02; N, 21.89\%. IR data(KBr, cm $\left.{ }^{-1}\right): 3288(\mathrm{~m}), 3237(\mathrm{w}), 1635(\mathrm{w}), 1606$ (m), $1572(\mathrm{~m}), 1475(\mathrm{w}), 1379(\mathrm{~m}), 1299(\mathrm{w}), 1232(\mathrm{w}), 1160(\mathrm{~s})$, $1080(\mathrm{w}), 996(\mathrm{w}), 958(\mathrm{w}), 811(\mathrm{w}), 668(\mathrm{w}), 584(\mathrm{w}), 521(\mathrm{~m}), 458$ (w), $419(\mathrm{w}) \mathrm{cm}^{-1}$.

$\left[\mathbf{M n}\left(\mathbf{N H}_{3}\right)_{6}\right]_{n}\left[\left\{\mathbf{M n}\left(\mathbf{N H}_{3}\right)\left(\mu-\mathbf{A s S}_{4}\right)\right\}_{2}\right]_{n}$ (6). Mn (55.0 mg, 1.0 $\mathrm{mmol})$, As (37.5 mg, $0.50 \mathrm{mmol}), \mathrm{S}$ (64.1 $\mathrm{mg}, 2.00 \mathrm{mmol}$ ), hydrazine monohydrate $(98 \%, 1.0 \mathrm{~mL})$, and aqueous ammonia $(25 \%, 0.5 \mathrm{~mL})$ were mixed by stirring for 10 minutes, and then the mixture was loaded into a PTFE-lined stainless steel autoclave of volume $10 \mathrm{~mL}$. The sealed autoclave was heated to $90{ }^{\circ} \mathrm{C}$ for 6 days and then cooled to ambient temperature. The yellow block crystals of $\mathbf{6}$ were collected with a procedure similar to that for the treatment of 1. Yield $67 \mathrm{mg}$ (38\% based on As). Elemental analysis calcd for $\mathrm{H}_{24} \mathrm{~N}_{8} \mathrm{~S}_{8} \mathrm{Mn}_{3} \mathrm{As}_{2}$ (6): calcd $\mathrm{H}$, 3.42 ; N, 15.84. Found: H, 3.28; N, 15.67\%. IR data $\left(\mathrm{KBr}, \mathrm{cm}^{-1}\right)$ : 3443 (m), 3254 (w), 3216 (w), 3149 (w), 1568 (m), 1535 (m), 1454 (w), 1383 (w), 1320 (m), 1278 (w), 1228 (w), 1181 (w), 1118 (m), 1051 (s), 824 (m), 711 (s), $622(\mathrm{w}), 534(\mathrm{~m}), 458(\mathrm{w}), 421(\mathrm{w})$.

\section{$\mathrm{X}$-ray crystal structure determinations}

Data were collected on a Rigaku Saturn CCD diffractometer at 293(2) K using graphite-monochromated Mo-K $\alpha$ radiation with a $\omega$-scan method to a maximum $2 \theta$ value of $50.70^{\circ}$. The intensity data sets were collected with a $\omega$-scan method and reduced with the CrystalClear program..$^{27}$ An empirical absorption correction was applied for compounds 1-6 using the multiscan technique. The structures were solved with direct methods using the program of SHELXS-97, ${ }^{28 a}$ and the refinement was performed on $F^{2}$ using SHELXL-97. ${ }^{28 b}$ All the non-H atoms were refined anisotropically. The hydrogen atoms were added geometrically and refined using the riding model. Technical details of data acquisition and selected refinement results are summarized in Table S1. $\dagger$

\section{Conclusions}

It has been demonstrated that hydrazine is a successful reaction media for the thermal synthesis of thioarsenate. A series of 1-D, 2-D and 3-D polymeric Mn(II)-thioarsenates have been prepared by hydrazine-solvothermal methods. The templating effect of hydrazine is influenced by the second ligand or solvent, which causes variable coordination modes between the thioarsenate anions and TM cations. The syntheses and properties of the title 
compounds indicate the possibilities of syntheses of new TM chalcogenidometallates with tunable structures by selecting the different coordinating solvents in hydrazine. Further studies on constructing new hybrid chalcogenidometallates with TM complex cation by hydrazine-solvothermal methods are in progress.

\section{Conflicts of interest}

There are no conflicts to declare.

\section{Acknowledgements}

This work was supported by the National Natural Science Foundation of China (NSFC, no. 21171123), and the project funded by the Priority Academic Program Development (PAPD) of Jiangsu Higher Education Institutions.

\section{Notes and references}

1 (a) C. L. Cahill, Y. Ko and J. B. Parise, Chem. Mater., 1998, 10, 19-21; (b) H. Li, M. Eddaoudi, A. Laine, M. O'Keeffe and O. M. Yaghi, J. Am. Chem. Soc., 1990, 121, 6096-6097; (c) L. M. Wu, X. T. Wu and L. Chen, Coord. Chem. Rev., 2009, 253, 2787-2804; (d) C. Slabbert and M. Rademeyer, Coord. Chem. Rev., 2015, 288, 18-49.

2 (a) N. F. Zheng, X. H. Bu, H. Vu and P. Y. Feng, Angew. Chem., Int. Ed., 2005, 44, 5299-5303; (b) L. N. Nie, G. F. Liu, J. Xie, T. T. Lim, G. S. Armatas, R. Xu and Q. C. Zhang, Inorg. Chem. Front., 2017, 4, 954-959; (c) C. Y. Yue, X. W. Lei, L. J. Feng, C. Wang, Y. P. Gong and X. Y. Liu, Dalton Trans., 2015, 44, 2416-2424; (d) K. Y. Wang, M. L. Feng, D. N. Kong, S. J. Liang, L. Wu and X. Y. Huang, CrystEngComm, 2012, 14, 90-94.

3 (a) M. Wu, T. J. Emge, X. Y. Huang, J. Li and Y. Zhang, J. Solid State Chem., 2008, 181, 415-422; (b) Q. C. Zhang, X. H. Bu, L. Han and P. Y. Feng, Inorg. Chem., 2006, 45, 6684-6687.

4 (a) S. Bag, P. N. Trikalitis, P. J. Chupas, G. S. Armatas and M. G. Kanatzidis, Science, 2007, 317, 490-493; (b) N. F. Zheng, X. H. Bu, B. Wang and P. Y. Feng, Science, 2002, 298, 2366-2369; (c) G. S. Armatas and M. G. Kanatzidis, Nat. Mater., 2009, 8, 217-222.

5 (a) T. K. Bera, J. I. Jang, J. H. Song, C. D. Malliakas, A. J. Freeman, J. B. Ketterson and M. G. Kanatzidis, J. Am. Chem. Soc., 2010, 132, 3484-3495; (b) Q. C. Zhang, I. Chung, J. I. Jang, J. B. Ketterson and M. G. Kanatzidis, J. Am. Chem. Soc., 2009, 131, 9896-9897; (c) Q. C. Zhang, I. Chung, J. I. Jang, J. B. Ketterson and M. G. Kanatzidis, Chem. Mater., 2009, 21, 12-14.

6 Q. C. Zhang, Y. Liu, X. H. Bu, T. Wu and P. Y. Feng, Angew. Chem., Int. Ed., 2008, 47, 113-116.

7 (a) N. F. Zheng, X. H. Bu and P. Y. Feng, Nature, 2003, 426, 428-432; (b) S. Haddadpour, M. Melullis, H. Staesche, C. R. Mariappan, B. Roling, R. Clérac and S. Dehnen, Inorg. Chem., 2009, 48, 1689-1698.

8 (a) M. J. Manos, K. Chrissafis and M. G. Kanatzidis, J. Am. Chem. Soc., 2006, 128, 8875-8883; (b) M. L. Feng,
D. N. Kong, Z. L. Xie and X. Y. Huang, Angew. Chem., Int. Ed., 2008, 47, 8623-8626; (c) X. H. Qi, K. Z. Du, M. L. Feng, J. R. Li, C. F. Du, B. Zhang and X. Y. Huang, J. Mater. Chem. A, 2015, 3, 5665-5673; (d) X. M. Zhang, D. Sarma, Y. Q. Wu, L. Wang, Z. X. Ning, F. Q. Zhang and M. G. Kanatzidis, J. Am. Chem. Soc., 2016, 138, 5543-5546.

9 (a) Q. C. Zhang, X. H. Bu, Z. E. Lin, M. Biasini, W. P. Beyemann and P. Y. Feng, Inorg. Chem., 2007, 46, 7262-7264; (b) M. L. Fu, G. C. Guo, X. Liu, W. T. Chen, B. Liu and J. S. Huang, Inorg. Chem., 2006, 45, 5793-5798; (c) G. N. Liu, X. M. Jiang, M. F. Wu, G. E. Wang, G. C. Guo and J. S. Huang, Inorg. Chem., 2011, 50, 5740-5746; (d) G. N. Liu, G. C. Guo, M. S. Wang and J. S. Huang, Dalton Trans., 2014, 43, 3931-3938.

10 R. L. Bedard, S. T. Milson, L. D. Vail, J. M. Bennett and E. M. Flanigen, Stud. Surf. Sci. Catal., 1989, 49, 375-387.

11 (a) W. S. Sheldrick and M. Wachhold, Coord. Chem. Rev., 1998, 176, 211-322; (b) W. S. Sheldrick, J. Chem. Soc., Dalton Trans., 2000, 18, 3041-3052;; (c) S. Dehnen and M. Melullis, Coord. Chem. Rev., 2007, 251, 1259-1280; (d) B. Seidlhofer, N. Pienack and W. Bensch, Z. Naturforsch., 2010, 65b, 937-975; (e) M. L. Feng, K. Y. Wang and X. Y. Huang, Chem. Rec., 2016, 16, 582-600.

12 (a) J. Li, Z. Chen, R. J. Wang and D. M. Proserpio, Coord. Chem. Rev., 1999, 190, 707-735; (b) J. Zhou, Coord. Chem. Rev., 2016, 315, 112-134; (c) K. Y. Wang, M. L. Feng, X. Y. Huang and J. Li, Coord. Chem. Rev., 2016, 322, 41-68.

13 (a) Y. Lin and S. Dehnen, Inorg. Chem., 2011, 50, 7913-7915; (b) J. R. Li, Z. L. Xie, X. W. He, L. H. Li and X. Y. Huang, Angew. Chem., Int. Ed., 2011, 50, 11395-11399; (c) Y. M. Lin, W. Massa and S. Dehnen, J. Am. Chem. Soc., 2012, 134, 4497-4500; (d) Y. M. Lin, W. Massa and S. Dehnen, Chem.-Eur. J., 2012, 18, 13427-13434; (e) Y. M. Lin, D. W. Xie, W. Massa, L. Mayrhofer, S. Lippert, B. Ewers, A. Chernikov, M. Koch and S. Dehnen, Chem.Eur. J., 2013, 19, 8806-8813; (f) Z. P. Wang, J. Y. Wang, J. R. Li, M. L. Feng, G. D. Zou and X. Y. Huang, Chem. Commun., 2015, 51, 3094-3097; (g) C. F. Du, J. R. Li, M. L. Feng, G. D. Zou, N. N. Shen and X. Y. Huang, Dalton Trans., 2015, 44, 7364-7372; (h) J. R. Li, W. W. Xiong, Z. L. Xie, C. F. Du, G. D. Zou and X. Y. Huang, Chem. Commun., 2013, 49, 181-183; (i) S. Santner, J. Heine and S. Dehnen, Angew. Chem., Int. Ed., 2016, 55, 876-893; (j) C. F. Du, N. N. Shen, J. R. Li, M. T. Hao, Z. Wang and X. Y. Huang, Chem.-Asian J., 2016, 11, 1555-1564; (k) C. F. Du, N. N. Shen, J. R. Li, M. T. Hao, Z. Wang, C. C. Cheng and X. Y. Huang, Dalton Trans., 2016, 45, 9523-9528.

14 (a) W. W. Xiong, E. U. Athresh, Y. T. Ng, J. F. Ding, T. Wu and Q. C. Zhang, J. Am. Chem. Soc., 2013, 135, 1256-1259; (b) J. K. Gao, Q. L. Tay, P. Z. Li, W. W. Xiong, Y. L. Zhao, Z. Chen and Q. C. Zhang, Chem.-Asian J., 2014, 9, 131-134; (c) W. W. Xiong, J. W. Miao, K. Q. Ye, Y. W. Wang, B. Liu and Q. C. Zhang, Angew. Chem., Int. Ed., 2015, 54, 546-550; (d) L. N. Nie, Y. Zhang, W. W. Xiong, T. T. Lim, R. Xu, Q. Y. Yan and Q. C. Zhang, Inorg. Chem. Front., 2016, 3, 111-116; (e) W. W. Xiong, G. D. Zhang and Q. C. Zhang, 
Inorg. Chem. Front., 2014, 1, 292-301; (f) L. N. Nie, W. W. Xiong, P. Z. Li, J. Y. Han, G. D. Zhang, S. M. Yin, Y. L. Zhao, R. Xu and Q. C. Zhang, J. Solid State Chem., 2014, 220, 118-123.

15 J. G. Speight, Lange's Handbook of Chemistry, CD\&W Inc, Laramie, Wyoming, 16th edn, 2004, P. 1.173, P. 1.387.

16 (a) M. Yuan and D. B. Mitzi, Dalton Trans., 2009, 31, 60786088; (b) D. B. Mitzi, Inorg. Chem., 2005, 44, 3755-3761; (c) M. Yuan, M. Dirmyer, J. Badding, A. Sen, M. Dahlberg and P. Schiffer, Inorg. Chem., 2007, 46, 7238-7240; (d) D. B. Mitzi, Inorg. Chem., 2005, 44, 7078-7086.

17 (a) M. J. Manos and M. G. Kanatzidis, Inorg. Chem., 2009, 48, 4658-4660; (b) Y. Liu, P. D. Kanhere, C. L. Wong, Y. F. Tian, Y. H. Feng, F. Boey, T. Wu, H. Y. Chen, T. J. White, Z. Chen and Q. C. Zhang, J. Solid State Chem., 2010, 183, 2644-2649; (c) Y. Liu, Y. F. Tian, F. X. Wei, M. S. C. Ping, C. W. Huang, F. Boey, C. Kloc, L. Chen, T. Wu and Q. C. Zhang, Inorg. Chem. Commun., 2011, 14, 884-888.

18 P. P. Sun, S. Z. Liu, S. F. Li, L. M. Zhang, H. Sun and D. X. Jia, Inorg. Chem., 2017, 56, 6152-6162.

19 (a) X. Y. Huang, J. Li, Y. Zhang and A. Mascarenhas, J. Am. Chem. Soc., 2003, 125, 7049-7055; (b) K. Z. Du, M. L. Feng, J. R. Li and X. Y. Huang, CrystEngComm, 2013, 15, 55945597; (c) K. Y. Wang, M. L. Feng, L. J. Zhou, J. R. Li, X. H. Qi and X. Y. Huang, Chem. Commun., 2014, 50, 14960-14963; (d) C. Liu, Y. Y. Shen, P. P. Hou, M. J. Zhi, C. M. Zhou, W. X. Chai, J. W. Cheng and Y. Liu, Inorg. Chem., 2015, 54, 8931-8936; (e) Y. Y. Shen, C. Liu, P. P. Hou, M. J. Zhi, C. M. Zhou, W. X. Chai, J. W. Cheng, Y. Liu and Q. C. Zhang, Chem.-Asian J., 2015, 10, 26042608; $(f)$ D. M. Yan, C. Liu, W. X. Chai, X. R. Zheng, L. D. Zhang, M. J. Zhi, C. M. Zhou, Q. C. Zhang and Y. Liu, Chem.-Asian J., 2016, 11, 1842-1848.
20 (a) J. Zhao, J. J. Liang, J. F. Chen, Y. L. Pan, Y. Zhang and D. X. Jia, Inorg. Chem., 2011, 50, 2288-2293; (b) D. X. Jia, J. Zhao, Y. L. Pan, W. W. Tang, B. Wu and Y. Zhang, Inorg. Chem., 2011, 50, 7195-7201; (c) C. Y. Tang, F. Wang, W. Q. Jiang, Y. Zhang and D. X. Jia, Inorg. Chem., 2013, 52, 10860-10868; (d) C. Y. Tang, Y. L. Shen, P. P. Sun, S. Z. Liu, J. Y. Han, Y. Liu, H. Sun and D. X. Jia, Eur. J. Inorg. Chem., 2016, 24, 3921-3926.

21 (a) M. L. Fu, G. C. Guo, L. Z. Cai, Z. J. Zhang and J. S. Huang, Inorg. Chem., 2005, 44, 184-186; (b) D. X. Jia, Q. X. Zhao, J. Dai, Y. Zhang and Q. Y. Zhu, Z. Anorg. Allg. Chem., 2006, 632, 349-353; (c) C. Y. Yue, X. W. Lei, Y. W. Tian, J. Xu, Y. Q. Bai, F. Wang, P. F. Zhou, X. F. Liu and F. Y. Yi, J. Solid State Chem., 2016, 235, 183-192; (d) R. Q. Zhao, X. Liu, J. Zhou, H. Xiao, P. Wang and X. Y. Zhang, J. Coord. Chem., 2016, 69, 3726-3734.

22 (a) J. L. Lu, F. Wang, Y. L. Shen, C. Y. Tang, Y. Zhang and D. X. Jia, J. Solid State Chem., 2014, 216, 65-72; (b) J. Y. Han, Y. Liu, C. Y. Tang, Y. L. Shen, J. L. Lu, Y. Zhang and D. X. Jia, Inorg. Chim. Acta, 2016, 444, 36-42.

23 (a) J. J. Liang, J. Zhao, W. W. Tang, Y. Zhang and D. X. Jia, Inorg. Chem. Commun., 2011, 14, 1023-1026; (b) J. J. Liang, J. F. Chen, J. Zhao, Y. L. Pan, Y. Zhang and D. X. Jia, Z. Anorg. Allg. Chem., 2011, 637, 445-449.

24 W. W. Wendlandt and H. G. Hecht, Reflectance Spectroscopy, Interscience Publishers, New York, 1966.

25 X. Wang, T. L. Sheng, S. M. Hua, R. B. Fu, J. S. Chen and X. T. Wu, J. Solid State Chem., 2009, 182, 913-919.

26 I. E. Grey and H. Steinfink, Inorg. Chem., 1971, 10, 691-696. 27 CrystalClear, Version 1.35, Rigaku Corp., Tokyo, Japan, 2002. 28 (a) G. M. Sheldrick, SHELXS-97, Program for Crystal Structure Determination, University of Göttingen, Germany, 1997; (b) G. M. Sheldrick, SHELXL-97, Program for the Refinement of Crystal Structures, University of Göttingen, Germany, 1997. 